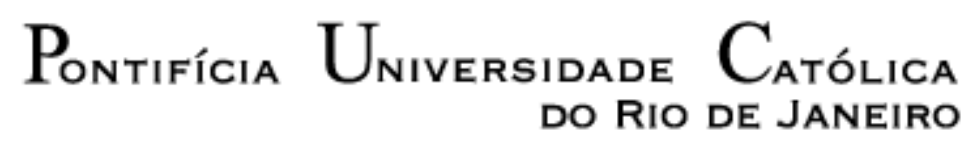

Michelle Christof Gorin

\title{
A PARENTELIDADE NO PÓS-DIVÓRCIO
}

Dissertação apresentada ao Programa de PósGraduação em Psicolo-gia Clínica da PUC-Rio como requisito parcial para obtenção do grau de Mestre em Psicologia Clínica.

Orientadora: Profa. Terezinha Féres-Carneiro 


\section{Pontifícia Universidade Católica $_{\text {atom }}$ DO RIO DE JANEIRO}

Michelle Christof Gorin

\section{A Parentalidade no Pós-Divórcio}

Dissertação apresentada como requisito parcial para obtenção do grau de Mestre pelo Programa de Pósgraduação em Psicologia Clínica do Departamento de Psicologia do Centro de Teologia e Ciências Humanas da PUC-Rio. Aprovada pela Comissão Examinadora abaixo assinada.

Profa. Terezinha Féres-Carneiro

Orientadora

Departamento de Psicologia - PUC-Rio

Profa. Andrea Seixas Magalhães Departamento de Psicologia - PUC-Rio

Prof. Edson Saggese

Instituto de Psiquiatria - IPUB/UFRJ

Profa Denise Berruezo Portinari Coordenadora Setorial de Pós-Graduação

e Pesquisa do Centro de Teologia e Ciências Humanas - PUC-Rio

Rio de Janeiro, 18 de dezembro de 2015 
Todos os direitos reservados. É proibida a reprodução total ou parcial do trabalho sem autorização da universidade, da autora e do orientador.

\section{Michelle Christof Gorin}

Graduada em Psicologia pela PUC-Rio e especialista em Psiquiatria e Psicanálise com crianças e adolescentes pelo Instituto de Psiquiatria da UFRJ. Participou do grupo de pesquisa na área de família com a orientadora Terezinha Féres-Carneiro. Atua na área clínica com crianças, adolescentes e famílias e é Membro Provisório da Sociedade Brasileira de Psicanálise.

Ficha Catalográfica

Gorin, Michelle Christof

A parentalidade no pós-divórcio / Michelle Christof Gorin ; orientadora: Terezinha Féres-Carneiro. - 2015.

$55 \mathrm{f}$; ; $30 \mathrm{~cm}$

Dissertação (mestrado)-Pontifícia Universidade Católica do Rio de Janeiro, Departamento de Psicologia, 2015.

Inclui bibliografia

1. Psicologia - Teses. 2. Família. 3. Divórcio. 4. Parentalidade. 5. Coparentalidade. 6. Narcisismo. I. Carneiro, Terezinha Féres. II. Pontifícia Universidade Católica do Rio de Janeiro. Departamento de Psicologia. III. Título. 


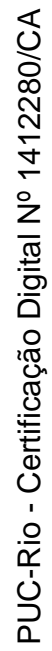

Para minha família,

por estar sempre perto. 


\section{Agradecimentos}

À Terezinha Féres-Carneiro, por compartilhar seu conhecimento e, especialmente, por acreditar no meu desenvolvimento acadêmico, profissional e pessoal.

À CAPES e à PUC-Rio, pelos auxílios que viabilizaram esse estudo e o meu mestrado.

Aos participantes desse estudo, pela disponibilidade e contribuição.

À Andrea Seixas Magalhães e ao Edson Saggese, pelas contribuições à minha dissertação como banca e mais ainda pelas trocas e supervisões imprescindíveis ao longo da minha formação.

À Lidia Levy, pelo estímulo constante e pela oportunidade de estágio em docência, que muito me ensinou.

À Rebeca Nonato Machado e à Renata Mello e a toda equipe de pesquisa coordenada pela professora Terezinha Féres-Carneiro, pelo trabalho em conjunto e pela ótima parceria.

Ao Miguel, meu analista, pela constante participação na construção do meu caminho.

À minha família e aos amigos, que se fazem sempre presentes na minha vida, cada um da sua forma. 


\section{Resumo}

Gorin, Michelle Christof; Féres-Carneiro, Terezinha. A parentalidade no pós-divórcio. Rio de Janeiro, 2015. 55p. Dissertação de Mestrado Departamento de Psicologia, Pontifícia Universidade Católica do Rio de Janeiro.

Esta dissertação de mestrado pretende discutir a parentalidade após o divórcio e suas repercussões na vida dos filhos. A partir das transformações nas configurações da família contemporânea, investigaram-se as consequências psíquicas do fim da conjugalidade no sujeito, em relação ao seu narcisismo e à possibilidade de elaboração da separação. Desenvolveu-se uma pesquisa qualitativa com quatro pais e quatro mães separados, baseada na realização de entrevistas semiestruturadas. Os resultados foram analisados de acordo com o método de análise de conteúdo. Verificou-se que a separação pode ser uma grande ferida no amor próprio dos membros do ex-casal, dificultando a vivência do luto pelo fim do casamento. Nesse contexto, as fronteiras entre a conjugalidade e a parentalidade ficam pouco delimitadas, afetando a relação com os filhos. Evidenciou-se que a forma na qual o divórcio foi vivido, individualmente, impacta as possibilidades de reorganização familiar após a ruptura. Nesse sentido, a coparentalidade se mostrou potencialmente difícil de ser exercida, implicando em grandes transformações na vida dos filhos.

\section{Palavras-chave}

Família; divórcio; parentalidade; coparentalidade; narcisismo. 


\section{Abstract}

Gorin, Michelle Christof; Féres-Carneiro, Terezinha. Parenting in PostDivorce. Rio de Janeiro, 2015. 55p. MSc. Dissertation - Departamento de Psicologia, Pontifícia Universidade Católica do Rio de Janeiro.

The purpose of this master's thesis is to discuss parenting after divorce and its repercussions in the children's lives. Taking into account the transformations in contemporary family settings, the study investigates the psychic consequences of the end of marital relations upon the subject, regarding his/her narcissism and the possibility of elaborating the separation. The author conducted a qualitative research with four fathers and four mothers, performing semi-structured interviews and studying the results using the content analysis method. Findings indicate that the separation may inflict a major wound in the self-love of former members of the couple, hindering the grieving process caused by the end of marriage. In this context, the boundaries between marital relations and parenting became unclear, affecting parent-child relations. Evidence shows that the way in which subjects experience divorce, individually, has an impact on the possibilities of family reorganization after the breakup. In this sense, co-parenting seemed potentially difficult, involving major transformations in the children's lives.

\section{Keywords}

Family; divorce; parenting; parenthood; co-parenting; narcissism. 


\section{Sumário}

$\begin{array}{ll}\text { 1. Introdução } & 10\end{array}$

2. Parentalidade $X$ conjugalidade: os desafios de compartilhar a convivência com os filhos após o divórcio

2.1. Como dois sujeitos tornam-se um casal conjugal?

2.2. Do casal conjugal ao casal parental

2.3. O Fim do casal conjugal: como permanecer um casal parental?

3. Método

4. Resultados e discussão

5. Considerações finais

6. Comemorações de aniversário: juntos ou separados?

Repercussões do divórcio parental nos filhos

6.1 A formação e o rompimento da conjugalidade

6.2 Divórcio dos pais: repercussões na vida dos filhos

7. Método

8. Resultados e discussão

9. Considerações finais

10. Conclusões

46

Referências bibliográficas 
"(...) De repente, não mais que de repente Fez-se de triste o que se fez amante $E$ de sozinho o que se fez contente. (...)" "Soneto da separação" - Vinicius de Moraes 


\section{Introdução}

A separação de um casal é um fenômeno que ocorre cada vez com maior frequência. A partir dessa situação, a família passa por inúmeras mudanças, desconstruindo a relação conjugal, para, ao longo do tempo, configurar novas relações de convivência. O divórcio e outras formações decorrentes dele afetam todos os envolvidos no sistema familiar, dos filhos aos parentes e amigos.

Carter \& McGoldrick (1995) entendem o divórcio como a interrupção no ciclo de vida familiar, ocasionando desarmonia quanto a ganhos e perdas dos envolvidos. Cada cônjuge precisa passar por processo de luto a fim de, por meio do reconhecimento das expectativas e dos investimentos feitos no casamento, lidar com os próprios sentimentos. Segundo as autoras, são necessários pelos menos dois anos para que a família possa prosseguir e reajustar-se. Durante esse período, esforços tornam-se imprescindíveis à adaptação da nova dinâmica familiar. Os filhos, envolvidos nesses conflitos, vivem, como os pais, uma fase instável (Manocherian \& Peck, 1995).

Brito (2007) salienta preocupação com a repercussão dos conflitos conjugais sobre os filhos em função do divórcio, ressaltando que a separação conjugal não deve ser reduzida a uma situação corriqueira. Para a autora, é necessário estar atento para que os filhos não sejam prejudicados no seu bemestar, quando os pais se separam.

É muito comum de acordo com Kehl (2003) especialistas de todas as áreas indicarem a família nuclear, tradicional, como a única responsável pela moral, ambiente seguro para o desenvolvimento do caráter do sujeito. No entanto, contesta esse paradigma, afirmando ser esse modelo um dos geradores das neuroses de hoje.

A autora faz um breve panorama histórico do conceito de família a partir do modelo burguês do século XIX, como objeto de reflexão sobre as mudanças ocorridas. Destaca como fatores de desconstrução estrutural a distribuição de poder no âmbito familiar - inicialmente entre homem e mulher, posteriormente entre pais e filhos - e a emancipação feminina diretamente relacionada à independência financeira e à maior escolaridade. Esses aspectos, intensificados pelo uso de anticoncepcionais e pela quebra gradual do tabu da virgindade, 
associados ao início dos divórcios e das separações, bem como aos casamentos experimentais não legalizados, demandaram novos questionamentos sobre o casamento clássico.

A família não é mais uma instituição sólida e estável, de acordo com Kehl (2003), mas funciona de acordo com os afetos. Um sentimento de dívida pode ser gerado em relação aos pais e avós, que possuíam o modelo idealizado de família e, desse modo, as funções de pais frente aos filhos são vividas com menos legitimidade. Para a autora, a família "desprivatizou-se", uma vez que a relação íntima entre as pessoas já não é mais prerrogativa do núcleo familiar primário. Além dos novos casamentos e separações, as pessoas, pela própria complexidade social, relacionam-se com indivíduos das mais diversas culturas e através de diferentes formas de afeto.

Kehl (2003) usa o termo "família tentacular" para descrever a família de hoje, que se tornou uma "árvore hiper-ramificada". Os projetos frustrados e retomados, além da esperança de felicidade, são, no entanto, marcas que os filhos carregarão em suas vidas. Para ela, a idealização que rege não só as relações entre pais e filhos, mas também entre marido e mulher, próprias dos conceitos burgueses não devem ser mais relevantes, para que se dê legitimidade às relações improvisadas. A família, como função primordial da constituição do sujeito para a vida em sociedade, precisa funcionar em diversos arranjos relacionais.

Todos os marcos históricos e sociais acima descritos e outros alteraram a configuração familiar na atualidade. Birman (2007) destaca o aumento da frequência com que casais trazem filhos de outros relacionamentos para novas uniões, que crianças passam a conviver em diferentes núcleos familiares simultaneamente e que filhos residem com apenas um genitor, constituindo famílias monoparentais. Para o autor, crianças e jovens são muito impactados por essas transformações, de forma que o processo de socialização propiciado pela família se transforma.

É nesse cenário que as mulheres foram em busca de suas próprias identidades e os homens mantiveram sua vida profissional de maneira central, gerando dificuldades na organização e divisão do cuidado com os filhos. Muitas mulheres passaram a realizar dupla jornada de trabalho, cuidando da casa e da prole e simultaneamente construindo sua carreira. Para Birman (2007), essas circunstâncias podem levar a uma ausência relativa das figuras parentais, que, 
nessas situações, passam a incluir cada vez mais babás, creches e escolas na educação das crianças. Surge certo anonimato no cuidado dos filhos, que, divididos entre tantas pessoas ou entre tantas prioridades e funções que existem hoje para os adultos, sentem as mudanças no narcisismo parental ora investido na prole. Novos modos de subjetivação em crianças e adolescentes são resultados dessas transformações.

Nesse sentido, vários outros autores discutem a família moderna, atribuindo a ela novas características e padrões, denominando-as de formas diversas. Além de família tentacular, há a descrição da família como democrática (Araújo, 2009), a família em desordem (Roudinesco, 2003) e a família relacional (Singly, 2007), dentre outros.

Essas diferentes formas de ser família se relacionam com o que Bauman (2004) denominou de amores líquidos. Para o autor, nossa época é caracterizada por mudanças frequentes e poucas permanências, pelo virtual e não pelo real, e por uma pressa que pode levar à superficialidade. Nesse sentido, vínculos são cortados com mais naturalidade, como forma de resolução de problemas, como um contínuo conectar e desconectar das relações, havendo pouca responsabilidade em relação ao outro. Assim, o afeto pode ser considerado instável na atualidade, levando a mudanças nas formas de ser casal e de ser família.

Nesse contexto, surgem não só novos personagens em cada família, mas também novas experiências para cada um de seus membros. Torna-se crucial refletir sobre as vivências emocionais dos filhos, a partir tanto do divórcio como também da constituição dos novos sistemas familiares. É nesse sentido que precisamos atentar para a parentalidade, exercida pelos pais, e como percebem os filhos no pós-divórcio.

As possibilidades de organização pós-divórcio encontram-se amplamente em pauta e seu debate é evidenciado pela Lei n. ${ }^{\circ} 13.058$ (Brasil, 2014), que instituiu a Guarda Compartilhada dos filhos entre os genitores como obrigatória. Apesar desse tipo de guarda ter sido regularizada e recomendada em Lei anterior, n. ${ }^{\circ} 11.698$ (Brasil, 2008), pouco se aplicava na prática em virtude da alta frequência do difícil relacionamento entre os ex-cônjuges, decorrente da separação, levando os juízes a não recomendarem o compartilhamento. Nesse sentido, o Projeto de Lei que levou à alteração da Lei justifica a necessidade dessa mudança, alegando que essa não seria necessária caso os genitores se 
relacionassem de forma positiva e tranquila. Logo, o objetivo é sim estimular e estipular o convívio de crianças e jovens com pai e mãe mesmo quando estão em conflito. O Projeto de Lei em questão também ressalta que a criança precisa se sentir "em casa" na residência de ambos os genitores, não deve ser colocada em posição adulta, tendo que fazer escolhas para onde vai e, com ênfase, destaca que "a guarda conjunta não pressupõe necessariamente um bom relacionamento entre os pais" (p.2).

O referido texto valoriza a capacidade do homem e da mulher de distinguirem a conjugalidade da parentalidade para um acordo que beneficie a prole, como fica evidente na seguinte passagem: "Obviamente, para os casais que, sabiamente, conseguem separar as relações de parentesco 'marido/esposa' da relação 'pai/mãe', tal Lei é totalmente desnecessária” (p.1). Nesse sentido, a relevância de ambos os genitores no cuidado com os filhos é ressaltada, bem como as dificuldades para que isso se concretize, em decorrência de conflitos conjugais após o divórcio.

O binômio conjugalidade-parentalidade aparece fortemente em questão nessas situações de pós-divórcio, questionando as repercussões do fim da primeira na segunda. Retomando a psicanálise, Freud (1914/2010) aponta o narcisismo como central para as vivências amorosas. Pretende-se neste estudo, a partir desse conceito, discutir os efeitos do término da relação conjugal no amor-próprio de cada sujeito envolvido e, com isso, as possibilidades de elaboração da separação.

O divórcio, quando vivido como uma ferida narcísica muito profunda, demanda um grande trabalho de luto (Freud, 1915/2010a) por parte dos membros do ex-casal, a fim de reorganizar os investimentos objetais. Assim, pode-se pensar a relevância da investigação a respeito das possíveis formas de experienciar a formação e o rompimento da conjugalidade, visto que isso tem grandes repercussões nas relações com os filhos.

Para essa investigação, realizou-se uma pesquisa qualitativa com oito participantes, sendo quatro homens e quatro mulheres, separados, com filhos entre 8 e 12 anos. Foi utilizado um roteiro semiestruturado em entrevistas individuais com cada sujeito. A partir dos relatos obtidos emergiram cinco categorias de análise: A dissolução da conjugalidade para as mulheres, A dissolução da conjugalidade para os homens, A experiência da parentalidade após o divórcio, 
Os comportamentos dos filhos frente ao divórcio na perspectiva dos pais e As festas de aniversário dos filhos: o encontro dos ex-cônjuges.

Para fins de apresentação dos resultados, essa dissertação foi dividida em dois estudos. O primeiro tem como tema central as possibilidades de compartilhamento, entre os ex-cônjuges, da convivência com os filhos. Os resultados ressaltam como a coparentalidade é marcada pela forma como a dissolução da conjugalidade se reflete em cada um dos genitores, evidenciando que o cuidado da prole está atrelado às possibilidades de organização pósdivórcio.

O segundo tem como foco as repercussões do divórcio parental nos filhos, ressaltando que quando não elaborado pelos pais pode gerar situações difíceis para a prole. As comemorações de aniversário exemplificam, a partir dos relatos dos entrevistados, as dificuldades de convivência entre os ex-cônjuges e as alterações na vida dos filhos.

Pretendeu-se, como objetivo geral, investigar as percepções de pais e mães acerca do exercício da parentalidade após o divórcio. Os limites entre conjugalidade e parentalidade, conflitos envolvidos no processo, bem como o funcionamento do dia a dia das famílias são pontos-chave da discussão. Espera-se ter contribuído para uma melhor compreensão de como os envolvidos vivem a separação e suas repercussões, produzindo conhecimento que ajude a promover mais encontros do que desencontros e, portanto, mais saúde emocional na família (Féres-Carneiro, 2003). 


\title{
2. Parentalidade $X$ conjugalidade: os desafios de compartilhar a convivência com os filhos após 0 divórcio
}

Resumo: Este artigo pretende discutir as particularidades do exercício da parentalidade após o divórcio. Desenvolveu-se uma pesquisa qualitativa com quatro pais e quatro mães separados, a partir da realização de entrevistas semiestruturadas. Os resultados foram analisados de acordo com o método de análise de conteúdo. Verificou-se que a dissolução da conjugalidade tem grande repercussão sobre a relação pais e filhos após a separação, explicitando dificuldades específicas desse contexto. Considera-se que a maneira em que homens e mulheres vivenciam o fim do casamento, marca as possibilidades de reorganização familiar e as peculiaridades da coparentalidade.

Palavras-chave: Família, divórcio, parentalidade.

\begin{abstract}
This article seeks to discuss the particularities of parenting after divorce. The authors conducted a qualitative research with four fathers and four mothers, performing semi-structured interviews and studying the results using the content analysis method. Evidence shows that the end of marital relations has major repercussions on parent-child relations after the divorce, displaying specific difficulties of this context. The authors conclude that the way in which men and women experience the end of the marriage marks both the possibilities of family reorganization and the peculiarities of co-parenting.
\end{abstract}

Keywords: family, divorce, parenting, parenthood, co-parenting.

O aumento do número de divórcios demandou que as famílias se reorganizassem de novas formas após a ruptura da conjugalidade. Com quem ficam os filhos é um questionamento recorrente dentro desse cenário e se constitui como motivo de conflito entre os ex-cônjuges. Isso porque a separação diz respeito à vida do casal e, para ambos exercerem a parentalidade, precisam se relacionar de alguma forma, visando que pai e mãe possam estar perto dos filhos.

Essa discussão se faz presente, hoje, especialmente por meio da valorização recente por parte da Justiça da guarda compartilhada dos filhos entre os genitores, priorizando a participação de ambos os pais no convívio com os 
filhos. Porém, muitas vezes, os conflitos entre os membros do ex-casal permanecem e surge a pergunta se é possível, de fato, compartilhar o convívio com os filhos quando não se compartilham mais tantos outros aspectos da vida.

Nesse contexto, este artigo tem como objetivo investigar tanto a percepção de pais e mães sobre o exercício da parentalidade e suas transformações após o divórcio como as diferenças envolvidas nesse processo entre os genitores. Os impactos da dissolução da conjugalidade na parentalidade são o ponto-chave nessa discussão.

Debruçar-nos-emos, então, sobre como ocorre a construção do casal e sobre o desejo de ter filhos, para depois podermos explorar mais profundamente as dificuldades do exercício da parentalidade após a separação. Dessa forma, nos questionamos sobre a complexidade da coparentalidade depois do divórcio, levando em conta que as discordâncias não cessam e que os filhos acabam sendo muito envolvidos nesses conflitos. As esferas conjugais e parentais se misturam, levando-nos a interrogar sobre as repercussões da dissolução da conjugalidade no sujeito e como isso transforma a experiência de ser pai e mãe.

\subsection{Como dois sujeitos tornam-se um casal conjugal?}

Pensando como dois sujeitos escolhem um ao outro para a formação de um casal, nos questionamos sobre o que direciona esses investimentos amorosos. O Eu é construído ao longo do desenvolvimento psíquico do sujeito, de forma que este tenta direcionar seus investimentos a determinados objetos, impulsionados pelo $I d$ e atendendo também ao mundo externo. A partir disso, cada um constitui suas relações objetais de acordo com seu modo de subjetivação.

Freud (1914/2010), a partir do conceito de narcisismo, descreve as possibilidades de escolha de objeto do sujeito, ou seja, discute a origem de determinados investimentos amorosos. O autor descreve dois caminhos para a escolha amorosa, o de apoio e o narcísico. O primeiro deriva do apoio inicial das pulsões sexuais nas de autoconservação, de forma que a pessoa, normalmente a mãe, que alimenta, se transforma no primeiro objeto sexual. Dessa forma, as pessoas que escolhem objetos do tipo apoio, investem em pessoas que se relacionam à figura da mulher que alimenta de alguma forma ou ao homem que protege. Enquanto que o segundo tipo se refere às pessoas que escolhem os objetos de amor tomando a si mesmas como referência. Assim, as pessoas que 
escolhem seus objetos de forma narcísica investem naquilo que são, foram ou gostariam de ser.

Freud (1914/2010) caracteriza, assim, de maneira geral, a forma principal de relação objetal do homem e da mulher. As mulheres tenderiam a viver o amor ao objeto de forma narcísica, desejando serem mais amadas do que amarem o objeto propriamente dito. Já os homens superestimam o objeto, de acordo com seu narcisismo original, e se empobrecem em termos libidinais para investir no objeto.

A partir do que cada um busca em sua escolha amorosa, pode se deparar com o narcisismo perdido da infância e com um ideal projetado pelo Eu, a partir do qual, mede-se a si mesmo e aos outros. Assim, no contexto das relações objetais pode haver uma idealização do objeto ou do próprio Eu e, uma vez superestimados, são mantidos em alto nível nos ideais (Freud, 1914/2010).

Nesse cenário, Freud (1914/2010) destaca que o amor-próprio e a vida amorosa se relacionam diretamente, pois a necessidade de ser amado pelo objeto pode levar ao sentimento de inferioridade. Para a forma narcísica de relação, o objetivo e a satisfação são resultados do ser amado e a idealização do objeto deriva da sensação de que ele possui o que falta ao Eu. Enquanto que, para a escolha objetal de apoio, será idealizado o objeto que repetir de alguma forma o modelo de amor infantil. Essa idealização é um trabalho interno, de fantasias, permeado pela imagem e fala dos pais, das pessoas e do social em geral.

Eiguer (2013) também destaca as fantasias e histórias individuais de cada um na formação do casal. Nesse sentido, o autor aponta a ideia de reconhecimento mútuo como base para a construção do vínculo. É a partir do reconhecimento de si e do outro que os parceiros podem se entender. Para isso, é necessário compreender que o vínculo entre os membros do casal envolve mecanismos inconscientes para além da individualidade de cada um, na intersubjetividade entre os dois.

O amor de casal, ainda segundo Eiguer (2013), surge quando um conhece no outro sua história, percebe seus desejos, compartilha experiências e decisões, entre outras coisas. Assim, o casal, ao se reconhecer mutuamente, legitimiza o vínculo de forma engajada, cristalizando o sentido da relação.

O narcisismo primário, supostamente já abandonado em parte na vida adulta, é reproduzido quando se tem filhos (Freud, 1914/2010). Nessa ocasião, as perfeições e prerrogativas infantis são revividas e projetadas na prole. Além disso, 
as questões de reconhecimento mútuo, na construção do vínculo conjugal, determinam as relações filiais futuras (Eiguer, 2013). É por esse caminho que duas pessoas tornam-se um casal e surge então a segunda pergunta: como um casal conjugal se torna um casal parental?

\subsection{Do casal conjugal ao casal parental}

Na construção do casal conjugal, há negociação entre os dois indivíduos envolvidos, de forma que ambos precisam abandonar uma parte de seus modelos e ideias, mas ao mesmo tempo manter, necessariamente, outras partes de seu espaço psíquico. Smadja (2011) fala desse processo, destacando o trabalho psíquico necessário para construir e manter a conjugalidade, transformando dois sujeitos em um grupo.

A partir da conjugalidade construída e constantemente investida por ambos os membros do casal, o autor aponta que o nascimento de uma criança aparece como traumático para os pais em termos psíquicos. Isso porque novamente demanda deslocamentos de identificações e investimentos para os sujeitos, um novo trabalho de elaboração psíquica precisa ser realizado, trazendo à tona conflitos, angústias e defesas (Smadja, 2011).

Nesse contexto, a parentalidade é uma construção, implicando mudanças para o casal e para seus membros individualmente. Em meio a essas mudanças, Hintz \& Baginski (2012) destacam que o nascimento do filho traz novas funções para o homem e a mulher, de forma que um tempo de adaptação se faz necessário. Além disso, essas novas responsabilidades de cada um em relação à parentalidade têm repercussões na relação conjugal.

Ziviani, Féres-Carneiro e Magalhães (2012) destacam que um casal engloba conteúdos psíquicos de dois sujeitos com histórias e vivências distintas. O conteúdo transgeracional e as identificações de cada membro do casal são oriundos de sua família de origem e levados para a formação da identidade conjugal. Para os autores, conciliar a conjugalidade e a parentalidade é um dos grandes desafios e torna o vínculo indissolúvel, pois a dissolução do casamento não acarreta na dissolução do casal parental. Isso significa que a responsabilidade, em relação à prole, constitui uma continuidade de vínculo em relação ao cônjuge.

Assim, a introdução de uma criança entre os dois parceiros é um acontecimento complexo. Smadja (2011) destaca as diversas facetas envolvidas no desejo de um casal conjugal de ter filhos. Para o autor, esse desejo é 
ambivalente para todos, e envolve não apenas investimento no objeto, mas investimento narcísico também. O que poderia levar a inúmeros questionamentos, como, por exemplo, se o desejo é ter um filho para si ou ter um filho do parceiro e, em última instância, se é possível separar o próprio desejo do desejo do outro.

$\mathrm{O}$ autor destaca que o desejo de ter filho é marcado de forma central pela diferença entre os gêneros. Para as mulheres, de forma geral, o filho aparece como complemento narcísico e fálico. Além disso, o filho ocupa um lugar erótico, relacionado à fantasia da experiência de maternidade, que se relaciona ao desejo incestuoso de ter um filho do pai, depois substituído pelo desejo do falo.

Enquanto isso, para o homem, um filho ocupa uma função narcísica, ligada à integridade sexual, por meio da criança como evidência de sua realização, e à imortalidade, através da experiência de transmissão e continuidade de si pela prole. A criança é comumente idealizada como extensão do narcisismo dos pais.

De qualquer forma, é comum para homens e mulheres que os filhos ocupem um lugar de interrogação no que diz respeito aos objetos de investimento e seu espaço no funcionamento conjugal (Smadja, 2011). O complexo de Édipo e o narcisismo, com suas marcas na constituição psíquica, orientam as possibilidades subjetivas no processo de tornar-se pai e mãe, com toda a história familiar e individual que acompanha o sujeito.

\subsection{A dissolução do casal conjugal: como permanecer um casal parental?}

O conceito de parentalidade se refere a um tornar-se pai e mãe como processo, consciente ou inconsciente, que passa pela história da família e pelo contexto sociocultural. A respeito do processo de construção da parentalidade, Lebovici (2006) descreve o ser pai ou mãe para além do biológico, ressaltando a descendência e o herdado da família, o que o sujeito transmitirá intergeracionalmente. "Assim, defino a parentalidade como o produto do parentesco biológico e da parentalização do pai e da mãe" (p. 22). Em relação à parentalização, este autor aponta que os filhos têm um papel ativo nesse processo.

Ainda de acordo com Lebovici (2006), a construção da parentalidade envolve elaborá-la no imaginário e lidar com os próprios pais. Segundo o autor, nos casos de famílias recompostas, esse processo é ainda mais complexo. É a partir dessa concepção que refletiremos sobre a parentalidade e o divórcio. 
Após o divórcio, há um término do casal conjugal, porém o vínculo como casal parental deve continuar, caso existam filhos. Isso se justifica, porque, independentemente do arranjo conjugal, os genitores permanecerão nos papéis de pais dos filhos. Quando duas pessoas se casam, há a construção de uma nova identidade. Essa identidade conjugal se desfaz aos poucos no divórcio, demandando uma redefinição da identidade individual de cada um dos membros do ex-casal. Esse processo é doloroso tanto para o homem quanto para a mulher e acontece de formas singulares. É um desafio para ambos, em meio aos conflitos e às mudanças, continuar a ser pai e mãe (Féres-Carneiro, 2003).

$\mathrm{Na}$ fase de reorganização da identidade individual, exercer a parentalidade de forma conjunta é complexo. Grzybowski \& Wagner (2010) apontam que a coparentalidade, após o divórcio, pauta-se pela conjugalidade e pelos vínculos emocionais entre pais e filhos. As autoras entendem que o vínculo que uniu o casal e os sentimentos antigos e atuais estão atrelados, inevitavelmente, à parentalidade, sendo difícil dissociá-los. Além disso, destacam que a ligação entre os genitores e os filhos antes e depois do divórcio, especialmente em relação à presença do pai, marca a coparentalidade, em função do, não raro, afastamento da figura paterna.

Os homens estão cada vez mais participativos no cuidado com os filhos, envolvendo trocas emocionais e afetivas nas relações. Porém, ao longo desses processos de reorganização familiar, as mulheres, ainda que se sintam satisfeitas com a maternidade, sentem o peso das responsabilidades do excesso de tarefas no dia a dia com filhos, casa e trabalho (Féres-Carneiro Ziviani, Magalhães e Ponciano, 2013).

Para Marinho (2011), a coparentalidade após o divórcio depende da cooperação entre os ex-cônjuges. É importante que os pais possam negociar, entre eles, as questões relacionadas ao cuidado com os filhos, apesar de estarem separados. Especialmente em um momento conflituoso, isso se torna mais difícil, visto que conjugalidade e parentalidade ficam sem um contorno que as delimitem. Dessa forma, a reestruturação da família deve ser inspirada pelo casal parental e não pelo conjugal (Schneebeli \& Menandro, 2014).

Com objetivo de discutir as especificidades do exercício da parentalidade após o divórcio, foi realizado um estudo de campo, que investigou as principais 
vivências de pais e mães separados, a fim de lançar luz sobre os pontos de maior tensão no que se refere ao exercício da parentalidade após a separação conjugal.

\section{Método}

\section{Participantes}

Participaram do estudo quatro mães e quatro pais, sujeitos independentes, oriundos das camadas médias da população carioca, separados há no mínimo um ano e no máximo sete anos, com filhos entre 8 e 12 anos que convivem com ambos os genitores. A escolha por esta faixa etária dos filhos ocorreu por ser uma época de dependência e de convivência com os pais, na qual surgem questões individuais e de autonomia.

As mães e os pais foram nomeados em grupos separados de 1 a 4 . As idades das mães variou entre 35 e 57 anos, separadas há pelo menos dois anos e no máximo seis anos, com filhos entre 10 e 12 anos. As idades dos pais variou entre 38 e 57 anos, separados há pelo menos dois anos e no máximo sete anos, com filhos entre 8 e 12 anos.

\section{Instrumento e procedimentos}

Os participantes foram entrevistados individualmente, tendo um roteiro semiestruturado como base, elaborado a partir da revisão da literatura sobre a percepção dos pais sobre a parentalidade e sobre a vivência dos seus filhos no pós-divórcio. As entrevistas foram gravadas e transcritas.

Cuidados éticos

O projeto de pesquisa foi aprovado pelo Comitê de Ética da PUC (processo n. ${ }^{\circ}$ 2015-07) e todos os participantes assinaram o Termo de Consentimento Livre e Esclarecido, autorizando a divulgação dos resultados em ensino, pesquisa e publicação.

\section{Resultados e discussão}

As entrevistas foram submetidas à Análise de Conteúdo conforme proposto por Bardin (2011). Essa proposta de estudo possibilitou a leitura do material coletado a partir das mensagens e conteúdos que os relatos revelam. Do relato dos participantes emergiram cinco categorias: $A$ dissolução da conjugalidade para as mulheres, A dissolução da conjugalidade para os homens, A experiência da parentalidade após o divórcio, Os comportamentos dos filhos frente ao divórcio na perspectiva dos pais e As festas de aniversário dos filhos: o 
encontro dos ex-cônjuges. Neste artigo serão apresentadas e discutidas as três primeiras categorias citadas.

\section{A dissolução da conjugalidade para as mulheres}

Considerou-se importante analisar de quem foi a iniciativa da separação e como cada um dos ex-cônjuges lidou com isso. Isso porque a separação envolve um processo de redefinição da identidade individual, uma vez que a identidade conjugal se rompe aos poucos (Féres-Carneiro, 2003) e, nesse momento de crise, são muitas as questões que atravessam a parentalidade a serem elaboradas.

As duas mães que se apresentaram mais queixosas em relação ao exercício da parentalidade dos ex-maridos tiveram o fim do casamento proposto pelos mesmos e não a partir de um desejo próprio.

Ele nunca perguntou pra mim, ela [a filha] precisa de alguma coisa? Ela está tá com plano de saúde? Não. Coisas básicas ele nunca perguntou. (...) Ele não tem nada no nome dele para eu não pegar ele, ele trabalha no cheque e no dinheiro, para eu não saber quanto ele ganha, ele ganha igual a mim. Falei para ele o que adianta ter filho, porque você não chega junto. (Mãe 1)

O pai ele não participa como a mãe. Por exemplo, tem que levar não sei aonde, a mãe vai fazer qualquer coisa para levar, para buscar; o pai, se der vai, se não der não vai. (Mãe 2)

Esses dados corroboram as postulações de Grzybowski \& Wagner (2010) de que a forma de organização da família, após o divórcio, é marcada pelo modo como ocorreu essa ruptura, ou seja, as possibilidades de exercício da parentalidade após a separação estão diretamente relacionadas aos conflitos envolvidos no término da conjugalidade.

Em relação às outras duas mães, aparecem três particularidades semelhantes relacionadas ao desejo da separação e à representação do casamento. Ambas engravidaram sem planejamento e, por isso, casaram com os respectivos namorados, descrevendo um casamento que não era o idealizado ou esperado. Além disso, foram elas que escolheram o divórcio, e ambos os ex-cônjuges sofreram com isso.

Eu acabei engravidando depois de um ano de relação. Um ano e pouquinho. E aí decidimos morar juntos, ele veio pra minha casa, eu falo que foi um casamento às avessas [risos], porque não teve planejamento e acabou que ele veio morar no meu apartamento. Mas nós moramos juntos durante seis anos, eu me separei. (Mãe 3)

A gente decidiu ficar junto por conta da gravidez, e aí não teve aquele amor de verdade, pelo menos da minha parte. Não foi 
aquela pessoa que você escolheu pra ser seu marido. Pra ser pai da sua filha. Aconteceu e a gente foi. (Mãe 4)

Essas duas mães fizeram queixas muito diferenciadas sobre os pais dos filhos e não atribuíram os problemas das funções parentais apenas aos defeitos dos ex-maridos, mas também os relacionaram a aspectos vulneráveis do funcionamento conjugal, anteriores ao divórcio.

Mas assim eu contribuí pra que essa relação estivesse nesse pé hoje, porque eu assumi responsabilidades que deveriam ter sido divididas, eu sou assim, de ir abraçando, abraçando, abraçando e isso não é bom. (Mãe 3)

Acho que sempre foi assim. Acho que também é uma culpa minha de não ter me colocado melhor na relação, tipo vamos dividir as coisas. (Mãe 4)

Essa diferença nos faz questionar o quanto as queixas sobre o ex-marido dizem respeito a uma tristeza das mulheres em relação a elas mesmas e ao término da conjugalidade. As mulheres que desejaram se separar têm menos queixas dos ex-cônjuges, conseguem se envolver melhor na situação, reconhecem a parte de cada um no conflito e trabalham mais para um diálogo comum em benefício dos filhos.

A posição queixosa em relação ao ex-marido, por parte de mulheres que sentiram muito a perda do homem e da família tal como tinham, pode reforçar os sentimentos negativos em relação aos homens. A parentalidade, que já envolve muitas funções e adaptações das questões de cada um (Hintz \& Baginski, 2012), se torna ainda mais complexa ao vincular de forma indissolúvel o homem e a mulher (Ziviani et al, 2012). Diante de todo sofrimento que gera a dissolução da conjugalidade, o exercício da parentalidade demanda que os membros do casal continuem a se relacionar e, para isso, precisam construir uma nova forma.

A partir de Freud (1914/2010), vemos como os investimentos amorosos das mulheres costumam ser do modo narcísico, ou seja, sua relação objetal acontece a partir delas mesmas e do desejo de serem amadas. Podemos pensar que o fim do casamento quando a escolha é do homem, fere narcisicamente a mulher ao não ser mais desejada. Quando, ao crescer como mulher, se sente objeto de desejo do outro, passa a ser referência ela mesma para suas relações objetais, de forma que quando não é mais objeto de investimento do outro, se perde de si mesma. É comum o casamento ocupar um lugar central na vida de muitas mulheres, de forma que tudo parte do fato de desejar ser amada pelo homem. 
Quando o homem não mais a deseja, toda sua vida perde o sentido, afinal, era o amor do outro que a fazia sujeito e mulher.

Assim, para as mães 1 e 2, a dificuldade de lidar com o a dissolução da conjugalidade pode se relacionar com o espaço central que o casamento ocupava em suas vidas, bem como o fato de serem amadas pelos maridos. O divórcio para essas mulheres ataca o amor-próprio, uma vez que se trata de um objeto perdido idealizado e detentor de tudo que falta ao próprio Eu (Freud, 1914/2010). Nesse cenário, é comum se sentirem em uma posição inferior, o que torna muito difícil a tarefa de se reorganizar como sujeito e dar continuidade à experiência de ser mulher e mãe.

As mães 3 e 4 não aparentavam ter com os ex-maridos uma relação narcísica central, sendo o próprio Eu ainda objeto de investimento individual, não tendo no amor do outro sua base. Já reconheciam as falhas dos companheiros durante o casamento, caracterizando uma menor idealização dos mesmos e, consequentemente, colocando o casamento em um lugar menos idealizado em sua subjetividade. Nessas situações, elaborar a dissolução da conjugalidade gera menos sofrimento psíquico, uma vez que o sujeito não depende totalmente do outro. O amor-próprio fica menos afetado e gera mais condições de reorganização dos investimentos objetais.

A partir das falas ilustradas, podemos observar a complexidade das relações entre ex-cônjuges após o divórcio, e como a qualidade da relação conjugal e dos ideais de casamento trazem consequências para a parentalidade. Esses dados vão ao encontro das afirmações de Schneebeli \& Menandro (2014) e de Marinho (2011) em relação a diferentes hábitos e rotinas causarem tensões, dependendo da capacidade de elaboração do conflito relacionados à separação conjugal.

\section{A dissolução da conjugalidade para os homens}

Nenhum dos pais participantes mencionou diretamente de quem partiu o desejo de se separar, mas dois pais (Pai 3 e Pai 4) relataram outros interesses da mulher (outro homem e religião) que influenciaram o término do casamento, e os outros dois (Pai 1 e Pai 2) ressaltaram que a separação teria sido desejo deles. Em seus discursos, ao falarem do divórcio, as queixas em relação às ex-esposas se fazem presentes, três pais (Pai 1, 3 e 4) reclamaram que elas falam mal deles para os filhos, questionam a educação que lhes dão ou criam problemas desnecessários. 
Muitas vezes porque a mãe fica pedindo pra ela "ó, liga pro teu pai e pede pra ele pagar não sei o quê". "Liga pra teu pai e pede isso". "Diz pro teu pai que a roupa que foi daqui não tá lá". Eu falo "não precisa me ligar, isso é coisa entre eu e ela (mãe)", ela me liga, manda e-mail, manda mensagem e pronto. Então fica tentando usar ela (filha) de pombo-correio. E colocando ela (filha) no meio das confusões, brigando com ela porque ela esqueceu a roupa aqui. (Pai 1)

Vou dar um exemplo muito simples. Meus filhos agora tão fazendo judô, direitinho, e eu tô querendo levar eles pro jiujítsu. O judô tem muita disciplina, o jiu-jítsu é meio aquele negócio de brigão, então tô lá, verifiquei, pesquisei, conheci o professor, a mulher do professor, vi que é um negócio legal, fiz dentro do possível... e a mãe fica toda assim dizendo "ah eu tenho que ver, acontecer", mas não vai lá ver nada e não acontece nada. Eu faço acontecer e ela fica numa coisa que me incomoda e tal, me atrapalhando. Papo furado, pouca ação. (Pai 3)

Outro dia ele chegou lá em casa dizendo que a mãe disse que eu deseduco ele. "Pai, minha mãe me falou que você me deseduca." "Por que eu te deseduco?" "Porque você me dá bala." "Pô cara, eu te vejo dois finais de semana por mês, durante dois dias, você me pede uma bala e eu te dou uma bala, você conta pra sua mãe, ela te diz que eu te deseduco." Aí eu falei "não vou te dar mais bala", aí ele "não vou contar mais porque eu quero bala". [risos] (Pai 4)

As reclamações desses pais em relação às mães dos filhos dizem respeito a problemas desnecessários de acordo com a percepção deles, como se elas estivessem querendo causar-lhes conflitos propositalmente. Fica em evidência a grande decepção dos homens em relação às mulheres e suas atitudes. Considerando que Freud (1914/2010) aponta que os homens costumam escolher seu objeto de investimento em forma de apoio, baseado na valorização do objeto em detrimento de si mesmo, é comum terem como referência sua primeira relação de amor, normalmente a mãe. Nesse momento do divórcio, as ex-esposas se afastam muito da posição daquela que cuida e alimenta. A idealização do objeto tem fim nesses momentos de conflito e sofrimento, tornando mais difícil para o homem se relacionar com a mulher. Isso porque não consegue mais encontrar nela o que antes amava.

A maioria dos pais participantes da pesquisa expôs dificuldade de se relacionar com as ex-esposas e especialmente de aceitar e compreender seus comportamentos. Quando não possuem mais a relação amorosa e idealizada com as mulheres que não mais os apoiam, o sofrimento é gerado pela impossibilidade de se relacionar de outra forma. 
O Pai 2, que não se queixou de sua ex-mulher, aparenta ter o melhor diálogo com a mãe do filho, entre os entrevistados.

Nos falamos diretamente. Se tem algo incomodando ela, a gente vai e resolve. (Pai 2)

Em relação a ele nunca teve muita briga, a gente sempre teve uma opinião parecida na forma de educar. (Pai 2)

A facilidade de relacionamento com a ex-mulher, de que esse pai dispõe, pode estar vinculada à melhor elaboração do término do casamento. Para ele, foi possível refazer seus investimentos em outros objetos e manter a relação com a ex-esposa. Quando esse processo é vivido de forma menos sofrida, há possibilidade de um maior diálogo para um exercício mais saudável da coparentalidade (Schneebeli \& Menandro, 2014; Marinho, 2011).

Na maioria dos exemplos citados os homens também demonstram grande sofrimento diante da separação e dos conflitos decorrentes dela. Assim como apontamos no caso das mães, os pais também têm uma ferida narcísica com a dissolução do casamento, ao terem investido na mulher como objeto de amor (Freud, 1914/2010). Todo fim de relacionamento prevê algum grau de sofrimento, porém, quanto maior o trabalho para reorganizar os investimentos objetais, maior esforço de elaboração demanda a situação (Féres-Carneiro, 2003).

A maioria dos pais participantes da pesquisa (pais 1, 3 e 4) relatam ter um distanciamento ou um conflito com a ex-mulher que agora, distante da posição materna antes idealizada (Freud, 1914/2010), desperta sentimentos ruins, chegando a um estranhamento sobre quem a pessoa se tornou.

Esses dados também corroboram os apontamentos de Eiguer (2013) sobre o reconhecimento mútuo como base para a constituição do vínculo, caso contrário, a relação fica sem sentido. As dificuldades de relacionamento descritas pelos participantes da pesquisa marcam a impossibilidade de reconhecer o outro em suas angústias, desejos e histórias individuais, levando ao rompimento do vínculo. A relação entre os ex-cônjuges favorece ou não o melhor convívio de ambos com a prole, sendo assim, vemos mais uma vez os impactos da dissolução da conjugalidade no exercício da parentalidade.

\section{A experiência da parentalidade após o divórcio}

Todos os participantes da pesquisa descrevem espontaneamente os aspectos positivos do exercício da parentalidade, dando ênfase ao amor e à gratificação da experiência de ser pai e mãe. Paralelamente, todas as mães 
também destacam outro lado da experiência, os aspectos negativos relativos ao cansaço, à falta de tempo, à grande responsabilidade e ao excesso de tarefas. Apenas um pai se refere a esse lado negativo da parentalidade e é o único que detém a guarda (Pai 3).

Ah, aquelas coisas clichês, melhor coisa do mundo. (Mãe 2)

Acho que é um amor que não cabe dentro da gente, o filho acaba sendo tudo na vida, tudo mesmo. (Mãe 3)

Acho ótimo, uma delícia, adoro criança, pena que cresce.

(Pai 1)

É muito gratificante pra você acompanhar isso, as coisas que ele vai aprendendo. (Pai 2)

Ah, melhor coisa do mundo. Sempre foi. Melhor coisa da minha vida. (Pai 4)

Dá muito trabalho, você não tem mais tempo pra você, você fica enlouquecida muitas vezes, cansada, com vontade de chorar, meu Deus tô cansada, mas é de uma alegria tão grande de você poder tá junto, ter aquela criatura do seu lado. (Mãe 4)

Primeiro que não vem com manual, né?, nem com controle remoto. (Mãe 1)

Cuidar dos meus filhos: responsabilidade. (Pai 3)

Esses relatos mostram que o exercício da parentalidade é prazeroso e satisfatório para todos, porém aqueles que fazem o acompanhamento diário e assumem as tarefas cotidianas sentem a maior responsabilidade (Féres-Carneiro et al, 2013). O acúmulo de funções se agrava quando o casal parental não divide o tempo e as tarefas ligadas aos filhos, de forma que um precisa assumir tudo que antes, durante o casamento, era dividido pelos dois.

A maioria dos participantes da pesquisa destaca as dificuldades em relação ao cuidado com os filhos quando há desencontro das regras e hábitos entre os genitores.

Porque o pai por não conviver com ela, ele nem briga, nem corrige. Ela diz: Se eu sair pelada na rua meu pai não tá nem aí. (...). Foi o que eu disse pra ele ontem, você pega ela pra passear, ela não mora comigo, ela é minha filha, eu tenho que educar ela. É diferente. Ela não mora, quando você tá lá, ele diz eu também sou pai, eu pego. Eu disse não, viver o dia a dia é que é o rojão. Educar, ensinar. Você fala como se ela morasse comigo e estivesse pronta. Mas ela não tá pronta, ela só tem 12 anos. (...) Eu falo pra ela, se você não quer regra você vai morar com seu pai. (Mãe 1)

Eu falo: quando você tiver na casa do seu pai as terças é importante você ter a rotina que você tem aqui em casa. Aí eu falo com ele, você tem que fazer o dever, demora umas duas 
horas, ela não pode começar às 10 da noite porque, se não, não acorda cedo, por causa da rotina dela e tal. Aí ela fala, mãe, a gente saiu pra jantar, a gente só chegou às 10 horas da noite, só pude fazer o dever 10 horas da noite. Ela vê que tem uma diferença. (Mãe 4)

Vou dar um exemplo, eu sou muito mais rígido, pode ser uma besteira mas pra mim é importante, de modos de comer na mesa. Então tem que segurar o talher direito, não pode colocar o cotovelo na mesa, essas coisas, a mãe não dá tanta importância para isso. Então olha só aqui tem que ser assim, na casa da mãe, ela relaxa um pouco mais. Aqui no almoço eu deixo almoçar vendo televisão na hora de ir pra escola, a mãe acha que não, que ver televisão junto com a comida é ruim, besteiras. (Pai 1)

Minha ex-mulher se converteu pra outra religião, virou evangélica, e aí ela começa a trazer muitos dogmas da religião dela pra criação, pro convívio dele no dia a dia e isso tá gerando muito conflito na cabeça dele. Por exemplo, quando ele tá comigo, lá em casa, vou à piscina, lá chamo minha irmã, a gente fica na piscina, começo a beber uma cerveja e ele fala "pai você não pode beber" (Pai 4).

As falas dos participantes lançam luz sobre as diferenças que passam a existir entre as ideias e rotinas dos ex-membros do casal, tanto enquanto homem e mulher, assim como enquanto pai e mãe. Durante o casamento, há uma identidade conjugal construída (Féres-Carneiro, 2003) e um vínculo intersubjetivo (Eiguer, 2013), que permitem ter mais ideias em comum, mantendo um dia a dia partilhado. No entanto, ao quebrar essa situação, cada um tende a construir sua vida da sua própria maneira, perdendo hábitos que costumavam ser comuns a ambos os cônjuges enquanto família.

Quando os participantes identificam as dificuldades no cuidado com os filhos, relacionando suas diferenças em relação aos ex-cônjuges, entendemos que é difícil exercer de forma conjunta a parentalidade. Além das diferenças que passam a existir, há pouco diálogo que permita alinhar o projeto vital que gostariam para a prole. Esse desencontro entre pai e mãe pode ser prejudicial para os filhos, nesse sentido, a literatura (Schneebeli \& Menandro, 2014; Marinho, 2011) ressalta a importância de criar um diálogo entre os membros do casal parental, independentemente do fim da conjugalidade.

Os desafios da coparentalidade após a separação do casal também são destacados por Grzybowski \& Wagner (2010). Estas autoras apontam que a conjugalidade e os sentimentos decorrentes do divórcio influenciam de maneira significativa a relação entre pais e filhos. Essa ideia se faz presente nas frequentes 
discordâncias entre ex-cônjuges em relação ao cuidado da prole, descritas pelos participantes.

Além disso, as dificuldades de exercer a coparentalidade após o divórcio se relacionam à origem do desejo de ter um filho (Smadja, 2011). Os investimentos na prole são de origem objetal e narcísicos, de forma que podem ser marcados pela orientação do desejo, por exemplo, de ter um filho para si ou para o cônjuge. Assim, a dissolução da conjugalidade pode questionar esse desejo original a respeito dos filhos, demandando que o lugar que eles ocupam seja reformulado e marcando a dificuldade de separar o desejo próprio do desejo do outro. A maioria dos participantes da pesquisa mostrou ser muito difícil compartilhar a convivência com o filho com o ex-parceiro, seja por não mais desejar qualquer relação com o mesmo ou por desejar o filho apenas para si.

Essa discussão vai ao encontro dos pontos levantados por Lebovici (2006) a respeito das particularidades da parentalidade. Para o autor, as questões de cada genitor, com sua própria história e fantasias, já fazem parte do ser pai e mãe, funções complexas por natureza. Assim, o divórcio, ao reorganizar o funcionamento familiar, demanda que os sujeitos reorganizem as relações estabelecidas previamente, exigindo trabalho psíquico.

\section{Considerações finais}

A partir do aumento do número de divórcios e da crescente discussão a respeito das organizações possíveis da família, após o término da conjugalidade, especialmente no que tange ao cuidado dos filhos, os dilemas da coparentalidade se fazem presentes. Observou-se que questões narcísicas orientam tanto a formação do casal como os sofrimentos relacionados à separação conjugal e relação com os filhos.

Colocou-se em questão como algumas mulheres que idealizaram menos o casamento, dependendo de forma menos central do amor do marido, tiveram mais facilidade em elaborar a separação, produzindo menos queixas e, através de um diálogo menos conflituoso, propiciaram um melhor convívio dos filhos com seus pais. Outras mulheres, pelo contrário, demonstraram ter no casamento e no marido a fonte central de investimento de seu narcisismo, demonstrando mais dificuldades no momento da separação e expressando mais queixas sobre os excônjuges. 
Em relação aos homens participantes da pesquisa, observou-se que a maioria não possui boa relação com a ex-mulher, fazendo queixas, especialmente no que tange à relação com os filhos. Na situação do divórcio, as mulheres podem se afastar da imagem idealizada materna que os homens antes tinham, sendo mais difícil construir algum outro tipo de relação. Os resultados encontrados apontam que o diálogo entre homens e mulheres nessa situação pode ser difícil, de forma que cada um se relacionará com a prole de sua forma individual e não alinhada pelo casal parental.

A partir das diferenças que surgiram entre homens e mulheres nesta pesquisa, apontamos que cada um pode buscar ser ressarcido da perda, ocasionada pelo divórcio, de sua própria maneira. É possível que as mulheres encontrem um retorno narcísico na relação com os filhos, enquanto os homens encontrem uma reparação para o amor perdido em outra mulher. Essas situações distintas geram dificultam a compreensão de como o outro vive o momento após o divórcio, aumentando os conflitos e as queixas sobre o outro.

Nesse cenário, discutiu-se que a origem do desejo de ter filhos e o espaço que eles ocupam na vida conjugal, antes comum ao casal, são transformados com a dissolução da conjugalidade. Enquanto projeto partilhado, o filho era narcisicamente investido como objeto para si ou para o outro, dentro daquela díade. Quando esta não existe mais da mesma forma, os resultados da pesquisa indicaram que pode ser delicado compartilhar a convivência e o cuidado em relação à prole com o outro que como objeto de amor e ódio, desperta ainda mais ambivalência nos afetos após o divórcio.

Concluiu-se que o divórcio envolve questões narcísicas centrais para cada um dos envolvidos, colocando em questão, a partir do que se ama e se deixa de amar, o amor-próprio de cada um. Nesse cenário, a parentalidade é, possivelmente, afetada pela ruptura da conjugalidade e pelas suas repercussões no psiquismo de cada cônjuge. É importante que possa haver uma reorganização dos investimentos, através de elaboração psíquica, a fim de que os ex-cônjuges possam se relacionar de uma nova forma e, assim, exercer a parentalidade de forma conjunta e saudável. 


\section{Comemorações de aniversário: juntos ou separados? Repercussões do divórcio parental nos filhos}

Resumo: Este artigo pretende discutir as repercussões do divórcio parental nos filhos, a partir da percepção dos pais. Foi desenvolvida uma pesquisa qualitativa com quatro pais e quatro mães separados, a partir da realização de entrevistas semiestruturadas. Os resultados foram estudados de acordo com o método de análise de conteúdo. Verificou-se que o divórcio implica em uma ferida narcísica importante para os sujeitos envolvidos, podendo gerar uma tendência a recalcar as representações do ex-cônjuge. Esse movimento pode dificultar a elaboração do luto pela dissolução da conjugalidade, trazendo dificuldades centrais para o exercício da parentalidade, uma vez que os filhos permanecem envolvidos em conflitos. Os filhos podem experimentar uma divisão em suas vivências com seus dois objetos de amor, pai e mãe, o que é ilustrado pelas comemorações de aniversários realizadas pelos genitores, em alguns casos em conjunto, e em outros, em separado.

Palavras-chave: parentalidade, divórcio, aniversário, recalcamento, divisão.

Abstract: This article seeks to discuss the repercussions of parental divorce on children from the parents' perception. The authors conducted a qualitative research with four fathers and four mothers, performing semistructured interviews and studying the results using the content analysis method. Evidence shows that divorce inflicts a major narcissistic wound in the subjects involved, which may generate a tendency to repress representations of the former spouse. This movement may hinder the elaboration of grief caused by the end of marital relations, since the children remain involved in conflicts. The children may suffer a division in their experiences with both love objects, father and mother, a condition illustrated by birthday celebrations held by parents, in some cases together, and in other, separately.

Keywords: parenthood, parenting, divorce, birthday, repression, division.

O divórcio, cada vez mais frequente, demanda de todo o núcleo familiar reflexões e adaptações nas relações intersubjetivas, na organização do dia a dia e 
principalmente nas questões internas individuais. Apesar de bastante comum, o fim do casamento continua a trazer desafios para todos os envolvidos por se constituir como um momento de ruptura na família.

Nesse sentido, é importante discriminar as esferas da conjugalidade e da parentalidade, uma vez que a separação é do casal e não da prole, de forma que os genitores permanecem um casal parental. Constitui-se como um desafio continuar a se relacionar com ex-cônjuge a fim de compartilhar o cuidado e as responsabilidades com os filhos.

Os conflitos e angústias que essas vivências despertam se refletem na forma como a parentalidade poderá ser exercida. As crianças são capazes de perceber os cuidados que recebem de seus pais, atribuindo valor significativo a essas experiências, de forma que o afeto das relações se mantém como pilar da constituição familiar atualmente, independente do arranjo conjugal (FéresCarneiro, Magalhães, Henriques e Machado, 2015). Assim, a relação entre os excônjuges é central na forma de os filhos viverem os conflitos.

Partindo dessas postulações, este artigo tem como objetivo investigar as repercussões do divórcio parental nos filhos a partir da percepção dos pais. A formação e o rompimento da conjugalidade e suas implicações para cada um individualmente e para o exercício da parentalidade são temas centrais nesse debate. Os aniversários dos filhos, momentos que dizem respeito a todo grupo familiar, são usados como exemplo significativo de como as relações após o divórcio podem se estabelecer. Nesse sentido, vamos focalizar o envolvimento dos filhos nos conflitos de seus pais e como vivem essas situações.

\subsection{A formação e o rompimento da conjugalidade}

O narcisismo é originalmente descrito como o amor pela imagem de si mesmo, através do mito de Narciso, que admira a si próprio. Freud (1914/2010), por meio desse conceito, discute os investimentos libidinais feitos pelo sujeito no próprio Eu e nos objetos. O autor destaca que é preciso amar para não adoecer, para isso, desloca-se parte da libido do Eu para um objeto externo. O amorpróprio está vinculado à escolha objetal, uma vez que ao ser amado, a escolha narcísica por aquele objeto é satisfeita.

A partir de Freud (1914/2010), vemos a relação entre a escolha amorosa e o narcisismo do sujeito, de forma que a ruptura da relação conjugal terá consequências narcísicas importantes. Uma vez que o sujeito ama seu cônjuge e é 
amado por ele, seu narcisismo está investido nesta relação amorosa e é investido por ela, seu término é, então, vivido como uma ferida narcísica.

Moguillansky \& Nussbaum (2011) apontam, a partir do conceito de vínculo, que a construção da relação intersubjetiva implica em uma mudança narcísica ilusória para o sujeito, uma vez que há uma fantasia de se fusionar ao objeto de amor, que seria idealmente igual ou complementar ao sujeito. Essa ilusão consiste na crença de ambos os membros do casal de terem se tornado apenas um com seu amor.

Nesse cenário, é possível compreender que o divórcio traz sérias repercussões na subjetividade de cada um dos cônjuges. Os investimentos libidinais precisam ser reorganizados a partir do fim do casamento, demandando trabalho de elaboração psíquica. Freud (1915/2010a) descreve a reação natural à perda de alguém como um processo de luto, podendo ser muito doloroso para o sujeito. É comum haver por um período um desinteresse pelo mundo externo e, aos poucos, a realidade mostra que não existe mais o objeto amado, e a libido precisa sair desse investimento à procura de outros objetos. Esse deslocamento da libido é muito sofrido para o sujeito, que vive a contradição entre a oposição às mudanças de seus investimentos e a realidade que se apresenta.

O objeto perdido se mantém no psiquismo do sujeito e tudo que está remetido a ele ganha ênfase. É aos poucos que a libido se desliga desse objeto para poder se ligar a outro (Freud, 1915/2010a). No caso do divórcio, os cônjuges perdem o objeto amado e precisam, através do luto, elaborar a perda para poder investir em novos relacionamentos. Inibições e falta de interesse são comuns nessa fase em que o Eu está tomado pelo processo de luto.

Quando há desilusão amorosa, pelos desencontros inevitáveis da vida a dois, Moguillansky \& Nussbaum (2011) apontam que é comum a sensação de não conhecer o parceiro nesse momento difícil, atrelando as dificuldades a algo que está sendo descoberto. A sensação de fracasso gera a desilusão, assim, sente-se que há algo negativo no outro, que foi escondido e que agora, encontrado, desperta ódio e decepção.

De acordo com os autores, é muito difícil renunciar à idealização do objeto amado, mantendo-se assim a esperança de que o amor dure para sempre. Dessa forma, a relação é regida por uma lógica binária, ou se está dentro desse vínculo ilusório ou não. Quando o vínculo se rompe, por divórcios ou conflitos de maneira 
geral, surge um sentimento de estar fora do amor, muito longe do ideal, gerando a sensação de fracasso.

Freud (1915/2010a) destaca que no luto normal todas as memórias e lembranças do objeto perdido, ainda investidas libidinalmente, são confrontadas com a realidade de que não há mais aquele objeto. Com o tempo, em nome da satisfação narcísica em manter sua própria existência, rompe-se o investimento objetal para se investir em novos objetos. Assim, para viver o luto é necessário se relacionar de alguma forma com o que se perdeu, pois as memórias referidas ao objeto perdido são essenciais para que o sujeito possa se despedir dele.

No entanto, permanecer vinculado ao amor que se perdeu, durante o longo e doloroso processo de luto, pode não ser possível para algumas pessoas. É comum que, como defesa, se tente afastar dos pensamentos toda e qualquer lembrança ligada ao objeto perdido. Freud (1915/2010b) destaca o mecanismo de recalque como o movimento de manter no inconsciente aquilo que é insuportável ao consciente, protegendo o sujeito do desprazer que essa representação gera através dessa divisão. Assim, diante de uma perda que gera muito sofrimento, é possível que se tente recalcar tudo que se relaciona ao que foi perdido para evitar mais dor, porém, o processo de luto fica mais difícil.

\subsection{Divórcio dos pais: repercussões na vida dos filhos}

Pesquisa realizada por Brito (2007), com filhos de pais separados, teve como objetivo aprofundar a compreensão das vivências destes na separação dos pais. Os resultados mostram não só que os que tiveram seus pais separados ainda criança não possuem memória sobre todos os membros vivendo na mesma casa, mas que também conhecem apenas o lado da história do genitor guardião. Já outros, apesar de crescidos, encararam o divórcio como algo traumático, pois não percebiam conflitos entre os pais. A autora destacou que os filhos sentem muito a saída de um dos genitores de casa, chegando a apresentar sintomas somáticos. Além disso, os filhos não viam possibilidade de conversarem com seus pais sobre a separação.

O estudo de Brito (2007) sinaliza que a maioria dos pesquisados se ressente pela separação dos pais e considera como momentos marcantes os vivenciados com eles quando ainda unidos. Indicam também que os jovens ou as crianças que presenciam os conflitos conjugais anteriores ao divórcio julgam a separação como decisão correta. Aqueles que convivem com ambos os genitores 
sentem falta da época em que os pais mantinham a relação conjugal. Para a autora, os filhos que apresentam menor número de queixas são os acolhidos tanto na casa da mãe quanto na do pai. Inclusos na realidade de ambos os genitores, continuam a sentir-se como o centro das atenções familiares.

No mesmo estudo, muitos dos pesquisados reclamam do fato de terem sido colocados no centro das brigas dos pais, rompendo com a ideia de que o divórcio é a solução para acabar com os conflitos. Dentro dessa perspectiva, evidencia-se um ponto de incômodo, a desqualificação de um dos ex-cônjuges.

Juras \& Costa (2011) apontam que os filhos que vivenciaram o divórcio dos pais percebem que, após a ruptura, eles não se relacionam bem e seu encontro gera conflito. Estes envolvem as crianças de diversas formas, atribuindo a elas responsabilidades que não cabem em seu papel familiar e sua idade. Assim, os filhos no centro dessas questões vivem conflitos de lealdade, são parte de comunicações indiretas entre os ex-cônjuges, ocupam posições hierarquicamente superiores na família, entre outras situações que são vividas com sofrimento.

Nesse sentido, as autoras destacam que na tentativa de compreender o conflito, os filhos podem demonstrar agressividade, insegurança e depressão como expressão do afeto envolvido nessa vivência, além de racionalizar buscando respostas para os dilemas. Nesse sentido, é muito importante atentar para o melhor interesse da criança, através da escuta da mesma.

Raposo, Figueiredo e Lamela (2011) apontam que os problemas decorrentes do divórcio, especialmente para os filhos, não se relacionam à separação dos pais em si, mas à mudança estrutural que a família vive. Assim, o modo como os pais vivem a situação se relaciona à competência parental que terão nessa circunstância. Para os autores, a resolução de conflitos entre os membros do casal parental, a coparentalidade positiva e o estado psicológico dos pais, entre outros, são aspectos centrais no modo como a criança viverá o divórcio.

Para os autores, é importante nos debruçarmos sobre os aspectos positivos que o divórcio pode trazer aos filhos, e não apenas olhar os pontos negativos. Para eles, os efeitos negativos da separação ocorrem nos primeiros anos, em um momento de crise e de reorganização subsequente. Mas o divórcio também pode ser vivido como um momento importante no desenvolvimento, que estimula a adaptação e a resiliência ao longo de tantas transições. 
De maneira geral, os autores expostos nessa articulação teórica explicitam as consequências e as marcas que envolvem a identidade pessoal e social das crianças e adolescentes, não só em períodos que antecedem o processo do divórcio, mas também durante as disputas litigiosas. Os filhos vivenciam os conflitos relacionais, sentindo-se, muitas vezes, culpados pela situação ou como estorvos à felicidade dos genitores. A não participação no processo aprofunda essas sensações, independentemente da idade em que se encontra o sujeito implicado nos embates entre os pais.

\section{Método}

\section{Participantes}

Participaram do estudo quatro mães e quatro pais, sujeitos independentes, oriundos das camadas médias da população carioca, separados há no mínimo um ano e no máximo sete anos, com filhos entre 8 e 12 anos que convivem com ambos os genitores. A escolha por esta faixa etária dos filhos ocorreu por ser uma época de dependência e de convivência com os pais, na qual surgem questões individuais e de autonomia.

As mães e os pais foram nomeados em grupos separados de 1 a 4 . As idades das mães variou entre 35 e 57 anos, separadas há pelo menos dois anos e no máximo seis anos, com filhos entre 10 e 12 anos. As idades dos pais variou entre 38 e 57 anos, separados há pelo menos dois anos e no máximo sete anos, com filhos entre 8 e 12 anos.

\section{Instrumento e procedimentos}

Os participantes foram entrevistados individualmente, tendo um roteiro semiestruturado como base, elaborado a partir da revisão da literatura sobre a percepção dos pais sobre a parentalidade e sobre a vivência dos seus filhos no pós-divórcio. As entrevistas foram gravadas e transcritas.

\section{Cuidados éticos}

O projeto de pesquisa foi aprovado pelo Comitê de Ética da PUC (processo n. ${ }^{\circ}$ 2015-07) e todos os participantes assinaram o Termo de Consentimento Livre e Esclarecido, autorizando a divulgação dos resultados em ensino, pesquisa e publicação.

\section{Resultados e discussão}

Para apresentação e discussão dos resultados as mães foram nomeadas de Mãe 1 a Mãe 4, e os pais de Pai 1 a Pai 4. As entrevistas foram submetidas à 
análise de conteúdo, conforme proposta por Bardin (2011). Essa proposta possibilitou a leitura do material coletado a partir das mensagens e conteúdos que os relatos revelaram. Do relato dos participantes emergiram cinco categorias: $O s$ comportamentos dos filhos frente ao divórcio na perspectiva dos pais, As festas de aniversário dos filhos: o encontro dos ex-cônjuges, $A$ dissolução da conjugalidade para as mulheres, A dissolução da conjugalidade para os homens e A experiência da parentalidade após o divórcio. Neste artigo serão apresentadas e discutidas as duas primeiras categorias citadas.

Os comportamentos dos filhos frente ao divórcio na perspectiva dos pais

Cada criança reage de forma singular frente ao divórcio dos pais, recebendo forte impacto da forma como os adultos estão vivendo o momento. A maioria das crianças não se queixou do divórcio por razões distintas. Mesmo insatisfeitas com a situação, de acordo com os genitores (Mãe 3, Mãe 4, Pai 3), três delas buscaram evitar conflitos na família.

Essa questão dele querer evitar atrito o tempo todo. Mas ele é bem... sem dúvida alguma, ele gostaria de ter mais tempo com o pai. (Mãe 3)

Será que eu volto? Aí, fui perguntar pra ela. "P, você gostaria que seus pais voltassem?" Ela falou não. Perguntei: "Você não tem tristeza, não tem..." "Não, mãe, é muito chato, meu pai é muito chato, não queria vocês dois juntos, ele tem uma namorada, eu quero que ele fique com a namorada dele". Aí eu falei: "E eu posso namorar?" Aí ela falou: "Pode, você tem que ser feliz". (Mãe 4)

$\mathrm{O}$ assunto é mais velado, bem fechado, me sinto até desconfortável de ver que eles não tão à vontade de falar nada de lá aqui. (...) (...) Isso que eu me sinto mal, eles não se sentem nem à vontade para falar disso. (...) É um assunto delicado, acho que aí eu falhei, eles não se sentem à vontade de falar nada da mãe, acho que o contrário também. (Pai 3)

Esses dados corroboram os encontrados por Juras \& Costa (2011), ao destacarem que a maior parte dos filhos de pais separados percebe que seus genitores não mantêm um bom relacionamento após o divórcio. Nesse sentido, os autores destacam que os filhos, frente aos conflitos dos pais, ficam em uma posição difícil, que desperta diversos sentimentos.

Ao tentar evitar conflitos entre os pais, os filhos demonstram perceber que a situação está sendo difícil não apenas para eles, mas também para os próprios genitores. De acordo com Freud (1914/2010), a relação amorosa está diretamente relacionada ao narcisismo do sujeito, uma vez que engloba a escolha e o 
investimento no objeto de amor e a experiência de ser amado pelo mesmo objeto. Assim, a ruptura dessa relação é como uma ferida narcísica, gerando muito sofrimento para os membros do ex-casal. $\mathrm{O}$ fracasso e a desilusão ganham ênfase na subjetividade do sujeito e, de forma decorrente, surgem sentimentos de ódio e de decepção em relação ao ex-cônjuge (Moguillansky \& Nussbaum, 2011).

No processo de luto, a realidade mostra que o objeto de amor não existe mais e é necessário reorganizar os investimentos libidinais (FREUD, 1915/2010a). A delicadeza da situação do divórcio, percebida pelos filhos ao se preocuparem com possíveis conflitos, marca que o processo de luto ainda está ocorrendo e há algo dessa ferida narcísica que ainda persiste dentro dos pais.

Voltando à questão dos filhos não se queixarem, o Pai 2 percebeu a insatisfação de seu filho quando ele relatou ter sentido sua falta. Apenas a mãe apontou um exemplo de sua filha criticando abertamente a separação dos pais. Outros dois pais (Pai 1 e Pai 4) e uma mãe (Mãe 2) não destacaram queixas dos filhos.

Fala que tava com saudade, de vez em quando, quando eu devolvo ele, e ele diz que vai ficar com saudades. (Pai 2)

Ah, mas não quero duas casas, não quero ir para a casa do meu pai, quero que meu pai venha para cá, você deixa meu pai voltar para casa?, meu pai não volta porque você não deixa. (Mãe 1)

Esses dados corroboram os resultados encontrados por Brito (2007), que apontam que a maioria dos filhos de pais separados se ressente de alguma forma pelo ocorrido. Seja pela reclamação explícita, seja pela saudade de um dos genitores, seja pela ausência de queixas pela preocupação com os pais, a maior parte dos filhos, de acordo com a percepção dos pais, demonstrou viver o divórcio de maneira sofrida, envolvida em conflitos, explícitos ou não. Como apontado pela autora, a reclamação sobre ficar no meio dos conflitos dos genitores e a impossibilidade de conversar com os pais sobre o divórcio seguem ocorrendo como repercussões importantes da separação conjugal para a prole.

Os relatos das entrevistas demonstraram que as mudanças, após o divórcio dos pais, geram sofrimento nos filhos. Como apontado por Raposo et al (2011), as repercussões do divórcio para os filhos estão mais ligadas às mudanças em si pelas quais a família passa, de ordem estrutural, e não ao divórcio efetivamente. A partir disso, é a forma de exercer a parentalidade nessa reorganização familiar que se relaciona com a forma que os filhos vivem esse processo. 
Os resultados da pesquisa mostraram que metade dos filhos dos participantes da pesquisa não fala sobre um genitor para o outro. Nesses casos, pela percepção dos pais, parece que não o fazem para atender ao pedido de um dos pais ou por conta de uma atmosfera familiar que impossibilita esse assunto.

Graças a Deus ela nunca trouxe nada de lá para mim. Também nunca levou. Nunca fala, ainda bem (risos). Ela separa completamente. E eu não pergunto nada e não ligo. (...) Eu também separo muito. O que que você fez hoje não. Quando ela chega da casa do pai eu não pergunto o que fez o que que não fez. (Mãe 2)

O assunto é mais velado, bem fechado, me sinto até desconfortável de ver que eles não tão à vontade de falar nada de lá aqui. (Pai 3)

Olha só, o que você faz com ela (namorada do Pai) lá fica lá, porque a mamãe não quer, eu não gosto, eu tenho ciúmes; $\mathrm{Ah}$, você tem ciúmes, tenho ciúmes, tô com ciúmes. Sempre conversei com ela e ela sempre entendeu. (Mãe 1)

Um dos problemas que aconteceu aqui foi que a mãe disse que ela tinha que falar tudo que acontecesse aqui, meio complicado do lado de lá. E tudo que era de lá era segredo. A mãe falava você não vai contar nada do que acontecer aqui. Naturalmente, "Ih, Pai, não fala pra mamãe que eu te contei", não podia contar. "Por que não podia?" "Ah, porque ela disse que não pode contar nada do que acontece lá." Eu falei, "Tá bom, pra mim segredo é só quando é errado. Aqui você pode contar tudo. Não faz nada de errado, não faz nada escondido, então pode contar tudo". (Pai 1)

As dificuldades evidenciadas nessas falas e persistentes após o divórcio mostram que o ex-cônjuge pode se tornar um tema velado entre pais e filhos. Há uma evitação do tema, como possível fuga da ferida narcísica que o rompimento conjugal gerou. Assim, quando Freud (1915/2010b) descreve o mecanismo de recalque como o meio para manter inconsciente aquilo que gera desprazer, explica o movimento de algumas pessoas ao tentarem ignorar e apagar tudo que se liga ao objeto perdido. Parece insuportável, em muitos momentos, para os pais manter qualquer tipo de ligação com o ex-cônjuge.

Assim, as restrições dos filhos, impostas pelos pais ou por eles mesmos, sobre intercambiar informações entre os membros do casal parental, corroboram a ideia de que há uma tentativa de recalcar a representação do ex-cônjuge como um movimento de esconder de si mesmo a perda muito sofrida. $\mathrm{O}$ narcisismo pode ser tão afetado pela separação que mostra a impossibilidade de lidar com isso conscientemente. 
Apenas o Pai 4 ressalta que o filho fala abertamente dos conflitos, gerando problemas para o filho:

Minha ex-mulher se converteu pra outra religião, virou evangélica, e aí ela começa a trazer muitos dogmas da religião dela pra criação, pro convívio dele no dia a dia, e isso tá gerando muito conflito na cabeça dele. Por exemplo, quando ele tá comigo, lá em casa, vou à piscina, lá chamo minha irmã, a gente fica na piscina, começo a beber uma cerveja e ele fala: "Pai, você não pode beber". (Pai 4)

Esses dados confirmam os apontamentos de Juras \& Costa (2011) ao destacarem que os filhos podem ser envolvidos em problemas de comunicação e experimentarem conflitos de lealdade como decorrência das dificuldades do divórcio. As mudanças na vida familiar podem trazer para as crianças vivências muito distintas no que diz respeito à convivência com cada genitor.

Os filhos precisam fazer um grande esforço de elaboração para se relacionar tanto com os contrastes que surgem entre os genitores como com o esforço de um dos pais em recalcar o que está remetido ao outro. Isso pode ser vivido de forma bastante confusa, representando uma divisão para a criança, tanto fora quanto dentro dela.

\section{As festas de aniversário dos filhos: o encontro dos ex-cônjuges}

$\mathrm{O}$ divórcio gera muitas mudanças na vida dos filhos. Toda a rotina e os hábitos familiares se reorganizam e a nova forma de convivência depende muito de como os adultos estão vivendo essa ruptura. Nesse contexto, comemorações de aniversário dos filhos, por representarem um rito tradicional e anual, comum a todos os integrantes da família, são exemplos interessantes para a investigação de como esse processo está sendo vivido pelos pais e, consequentemente, pelas crianças.

A maioria dos participantes da pesquisa não comemora o aniversário do filho em conjunto com o outro genitor, realizando festas separadas. Dentre eles, o Pai 1 relata que a filha gostaria que a mãe estivesse presente na festa, mas ele não deseja que esse encontro ocorra. Apenas a Mãe 3 relata ter convidado o outro genitor, mas que ele não compareceu por vontade própria:

Iiiih, ele faz uma festa e eu faço outra. É horrível. (Mãe 4)

Sempre eu faço a festa (...). A mãe não vem. Até quer vir, mas eu não quero que venha, porque cria um clima. Os nossos amigos todos ficaram meus amigos, não ficaram amigos dela, todos, sem exceção. E ela brigou com esses amigos, ficou um clima muito ruim. Então, misturar não ia dar certo. (...) Ela 
gostaria que a mãe viesse. E aí eu digo que não. A mãe fica insistindo pra vir, de propósito, pra criar a coisa... mas não... (Pai 1)

Eu dou uma festinha, bolo aqui, e ela lá e tal. (Pai 3)

Este ano, por exemplo, ele passou comigo o final de semana anterior ao aniversário dele, acho que caiu numa terça-feira, ele ficou comigo no final de semana, a gente comemorou no final de semana. E no final de semana seguinte ela fez uma festa em C (cidade perto), justamente pra não envolver minha família, pra não me envolver, e tá sendo tudo assim, separado. Eu faço uma coisa da minha família e ela faz lá. (Pai 4)

Depois da separação, os aniversários eu organizo e o pai não participou. (...) a gente sempre chama. (...) teve ano que tava trabalhando, sempre tem alguma coisa. Não vou falar que não quis, mas sempre tem um motivo. (Mãe 3)

O divórcio afeta diretamente o exercício da parentalidade, uma vez que é muito difícil para os pais manterem sua convivência após a separação. O encontro entre pais e filhos fica submetido à possibilidade ou não de encontro dos pais, inclusive em situações de comemorações, onde o foco prioritário poderia ser a criança e não os adultos. Os aniversários, como outras situações da vida das crianças, são alterados por conta dos desentendimentos parentais.

Como apontado anteriormente, há um esforço dos pais em recalcar (Freud, 1915/2010b) tudo que diz respeito ao ex-cônjuge, na tentativa de evitar sofrimento. Porém, como destacado pelo mesmo autor, é a partir das lembranças do objeto perdido que se pode retirar o investimento libidinal feito nele, a fim de escolher novos objetos. A tentativa de recalcamento das representações do excônjuge ou do casamento e do seu fim torna o luto um processo mais difícil. Acredita-se que eventos como aniversários, que promovem o encontro com toda a família da criança, trazem à tona o sofrimento envolvido no fím do casamento. Assim, novamente, tenta-se evitar esse encontro, mantendo o ex-cônjuge, o máximo possível, à distância.

Colocamos em questão as repercussões dessa tentativa de recalcamento para os filhos, ou seja, como a prole vivencia a situação em que um dos pais se esforça em apagar o outro de suas lembranças. Como apontado por Freud (1915/2010b), esse mecanismo de defesa contra um forte desprazer gera uma divisão no sujeito, levando para o inconsciente certas representações. Para os pais, comemorações separadas evitam que revivam o divórcio e toda a dor nele envolvida, ao não precisarem reencontrar o ex-cônjuge, mas para os filhos essa 
divisão pode ser vivida com sofrimento, uma vez que eles têm ambos os genitores como objeto de amor. O exemplo de duas festas de aniversário ilustra essa experiência de divisão que a criança pode viver. Como apontado por Brito (2007), se os conflitos permanecem após o divórcio, os filhos continuam envolvidos em brigas após o fim do casamento dos genitores.

Dentre os participantes, apenas a Mãe 1 e a Mãe 2 e o Pai 2 fazem comemorações de aniversário em conjunto. Sendo que a Mãe 1 apenas por insistência da filha, sendo uma situação difícil para ela.

Não fiz festa, fiz um bolo em casa e ela disse: "Meu pai pode vir? Quero meu pai e minha mãe juntos". Aí eu respirei fundo três vezes e deixei ele ir." (Mãe 1)

É, organizei, ele pagou e chamei. Depois teve outros aniversários sim... (Mãe 2)

Ele vai até fazer aniversário agora, a gente vai fazer um churrasco no clube, e vai ser junto, a festa. Nunca teve esse negócio de festa separada, nunca teve nada disso, sempre junto. (...) Aí também divide. Meio a meio. (Pai 2)

Esses participantes ilustraram as possibilidades de negociações para realização das comemorações dos filhos em conjunto. Não aparenta ser algo desejado por nenhum dos participantes da pesquisa, mas sim um esforço em nome do melhor interesse do filho. O pedido da filha da Mãe 1 evidenciou seu desejo de manter apenas uma comemoração para si e pode ser interpretado como uma tentativa de não ter que dividir seu aniversário e a si mesma. Quando as lembranças da conjugalidade e da sua dissolução são mais suportáveis e elaboradas, é possível conviver com o ex-cônjuge e não tentar recalcá-lo (Freud, 1915/2010b).

Essa vivência conjunta dos pais permite que os filhos vivam menos essa divisão entre os genitores, como ilustrou a fala do Pai 2, ao enfatizar que nunca realizaram festas separadas. Nesse sentido, a realização de festas dos filhos em conjunto ou em separado aponta para maior ou menor possibilidade dos genitores de resolução de conflitos e de coparentalidade positiva, aspectos centrais para a forma como os filhos viverão o divórcio de acordo com Raposo et al (2011).

Esses dados corroboram as postulações de Brito (2007) a respeito dos filhos menos queixosos em relação ao divórcio serem aqueles que foram incluídos na vida de ambos os genitores, mantendo-se no centro da família, ou seja, com menos divisões. A formação da identidade de um sujeito comumente envolve 
questionamentos acerca de sua origem, de seu nascimento e do sentindo de sua existência. Podemos pensar que o divórcio amplia e, possivelmente, complexifica dúvidas relacionadas a essas questões.

Quando isso não ocorre, os filhos podem viver com angústia esses momentos de encontro entre os pais. Chama atenção que três pais (Mãe 2, Mãe 4, Pai 3) notaram que seus filhos ficam tensos em situações em que os pais se encontram.

Ela não reclamou nada, ela não quer que encontre, mas nesse dia tinha que encontrar. (...) Eu não sei. De repente, eu posso ter passado isso para ela, porque eu não quero encontrar, posso ter passado isso. (Mãe 2)

Mas ela nem se queixa nem faz comentário sobre isso. Esse negócio, acho que ela viu tanta briga, tanta confusão, acho que ela não quer ver a gente junto. (Mãe 4)

Eu dou uma festinha, bolo aqui, e ela lá e tal. (...) [- E seus filhos reclamam disso?] Isso que eu me sinto mal, eles não se sentem nem à vontade para falar disso. Se eu disser: "Filhos, preciso falar com vocês", eles já vão tremer na base. (Pai 3)

Esses impasses que vivem os filhos se relacionam com a impossibilidade de conversar a respeito do divórcio e com o ressentimento pela separação dos pais, decorrente de tantos conflitos, como apontado por Brito (2007). Quando o divórcio gera muito sofrimento para algum dos membros do ex-casal, há a tendência a recalcá-lo (Freud, 1915/2010b) e também tudo que está ligado a ele, de sua vida e dos filhos também, implicando uma divisão que afasta a separação dos pensamentos conscientes. Em momentos que a realidade enfatiza o divórcio e ele não pode ser recalcado pelo sujeito, conflitos e angústias podem surgir. Nessas situações, em geral de encontro entre os genitores, um conteúdo insuportável vem à tona, remetido às questões narcísicas importantes.

Ao se envolverem no conflito do divórcio, os filhos acabam assumindo responsabilidades e se preocupando com o bem-estar dos pais, como as falas já demonstraram. Nesse sentido, metade dos pais participantes (Mãe 1, Mãe 2, Mãe 3 e Pai 4) da pesquisa percebeu seus filhos como maduros, relacionando em parte, tal maturidade, à vivência do divórcio.

Ela disse que bem gostou de um menino, mas disse pra ele que não quer "porque a senhora ia ficar muito preocupada, agora é dona do próprio negócio, com problema no trabalho, tá muito nervosa, muito estressada". [- "Então ela é superpreocupada contigo?”] - "Ela é (...)". (Mãe 1) 
Você acha que ela fica mais esperta porque tem que administrar essa situação? Talvez, ela é totalmente autônoma, totalmente autônoma. (...) E ela quer resolver tudo. Então ela chama o táxi e diz "estou no aguardo" (...) . A gente vendo o que ia fazer, de repente, ela já tinha entrado, arrumado a mesa. De repente, isso é um fator. (Mãe 2)

O E é muito maduro, não sei se por que conviveu muito com adulto, sempre foi uma criança bem falante sobre tudo, bem resolvida. (...) Porque de alguma maneira ele se sente o homenzinho da casa, quer saber quem vai, se eu vou receber amigos, onde que eu vou, o que que eu faço. Então, assim, é muito engraçado. Ele é muito atento, vê se trancou a porta, coisas assim, que ele sempre... agora eu tô sem empregada temporariamente, que a menina que trabalhava lá em casa em dezembro saiu, aí ele pergunta: "Mamãe, você quer que eu te ajude a fazer alguma coisa?". E eu penso, eu nunca ofereci ajuda pra minha mãe. Então, ele é muito pró-ativo, solidário. (Mãe 3)

Ele é maduro, acho que ele amadureceu muito com essa situação toda, ele acabou tendo um crescimento forçado, muita mudança. (Pai 4)

O amadurecimento das crianças, como repercussão do divórcio parental, pode ser sinal de que a crise e os conflitos foram vividos de maneira resiliente, demonstrando capacidade adaptativa (Raposo et al, 2011). Momentos de transformação intensa podem ser caracterizados como centrais no desenvolvimento, não apenas como fonte de efeitos negativos, mas como desafios e dilemas que potencializam o crescimento.

As vivências dos filhos após o divórcio dependem muito da forma como o casal parental está lidando com a dissolução da conjugalidade. As festas de aniversário lançaram luz sobre a importância de elaboração do luto pelo término casamento por parte dos pais, para que se possa exercer a parentalidade de forma conjunta.

\section{Considerações finais}

O divórcio traz desafios para toda a família, de forma que os envolvidos precisam elaborar a dissolução da conjugalidade, própria ou dos pais, a fim reorganizar os investimentos, as relações e o dia a dia. Nesse contexto, o exercício da coparentalidade vem se mostrando como um desafio importante para os ex-cônjuges, podendo alterar as relações pais e filhos no pós-divórcio.

Em relação aos comportamentos dos filhos frente ao divórcio, na perspectiva dos pais, observou-se que cada criança passa por essa situação de sua própria maneira, mas sempre impactada pela forma como está lidando com a 
separação. Comportamentos de evitação de conflito, de dificuldade de expressar a insatisfação, de impossibilidade de conversar sobre o divórcio ou a respeito de um genitor para o outro foram encontrados de forma recorrente nessa situação.

Nesse sentido, foi destacado que os pais podem sofrer o fim da conjugalidade como uma ferida narcísica, com grande sensação de fracasso e ódio do ex-cônjuge. É necessário passar por um processo de luto, a fim de elaborar a perda do objeto e poder investir em novos objetos. Quando tudo que está remetido ao ex-cônjuge, gera um sofrimento insuportável, há uma tendência a recalcar o que diz respeito a ele, como tentativa de esconder todo esse sofrimento. No entanto, isso dificulta o processo de luto e o sofrimento guardado vem à tona em situações de encontro, como os aniversários dos filhos.

Estes são comemorados de forma separada, cada filho tem duas festas de aniversário, uma com o pai e outra com a mãe, na maioria das vivências dos entrevistados. Nesses casos, questionamos se a evitação desse encontro e a tentativa de recalcamento do que se relaciona ao divórcio pode gerar para os filhos uma experiência de divisão. Esta coloca os filhos em uma posição delicada, pois se veem divididos entre seus dois objetos de amor, pai e mãe, no que diz respeito a amar e a ser amado, gerando angústia.

Assim, apesar de muitas vezes o divórcio ser uma escolha que visa ao fim dos conflitos conjugais, é comum os filhos permanecerem em uma situação de divergência após a separação de seus pais. Apesar das dificuldades destacadas nessas vivências, também foram encontrados dados sobre crianças que passaram por essa situação e apresentaram grande resiliência e capacidade adaptativa.

Concluiu-se que o divórcio parental, de acordo com a percepção dos pais, tem grandes repercussões nos filhos, tendo em vista a necessidade de separar com clareza o que é da esfera da conjugalidade da esfera da parentalidade. Acredita-se que a elaboração do fim da conjugalidade, em vez de seu recalcamento, permite aos pais exercer a parentalidade de maneira mais saudável, evitando que os filhos ocupem posições difíceis diante dos conflitos e se sintam divididos entre seus genitores. 


\section{Conclusões}

A partir do que se discutiu nesta dissertação, o exercício da parentalidade após o divórcio é muito influenciado pela forma como ocorreu a dissolução da conjugalidade e como cada um dos membros do casal viveu essa experiência. Assim, o divórcio tem repercussões importantes na organização familiar, especialmente no que diz respeito aos filhos, visto que altera todas as relações do grupo.

Desde a família nuclear tradicional moderna, a família vem atravessando diversas transformações, inicialmente apontadas nesse trabalho, destacando o aumento do número de divórcios e de novas constituições familiares (Kehl, 2003; Birman, 2007). Assim, entende-se que as mudanças são de diversas ordens, como sociais, históricas e também psíquicas, uma vez que envolvem e são envolvidas pela subjetividade de cada sujeito. Diversos autores (Araújo, 2009; Singly, 2007; Bauman, 2004; Brito, 2007, Féres-Carneiro, 2013) descrevem esse processo de mudanças, visando a acompanhar e compreender como hoje as pessoas se vinculam. Nessa mesma perspectiva, este estudo mostra como cada grupo familiar se constitui de forma singular e está em permanente construção.

Nesse contexto, cada família no pós-divórcio precisa encontrar sua própria maneira de passar por essa ruptura. Os dados encontrados foram discutidos a partir do conceito de narcisismo (Freud, 1914/2010), levando em consideração que a conjugalidade é construída a partir das escolhas objetais e dos investimentos do sujeito. O fim da mesma gera sofrimento e demanda trabalho em termos psíquicos. A discussão desse trabalho apontou que a necessidade de retirar o investimento do ex-cônjuge, para investir em outros objetos, ou seja, elaborar o luto (Freud, 1915/2010a) pelo objeto perdido, é uma tarefa que envolve muita dor e desafia cada sujeito em relação às suas questões pessoais. Esse processo se mostrou difícil para muitos participantes e muitas vezes insuportável, sendo preferível recalcá-lo (Freud, 1915/2010b) e não enfrentar a dor da perda. Nessas situações, o outro é quase que escondido, como um tema a ser evitado nos pensamentos, podendo levar a prole a posições difíceis. Isso porque o esforço de um genitor em recalcar o outro impede que ambos sejam integrados em termos psíquicos para os filhos, gerando uma experiência de divisão. 
A dificuldade em relação a enfrentar o divórcio foi relacionada nessa pesquisa com o lugar que o casamento ocupava anteriormente na vida psíquica do sujeito. O nível de idealização, as expectativas, a origem do desejo da separação, entre outros, são componentes importantes para essa experiência de ruptura. Assim, quanto mais central na vida do sujeito era o casamento, no que diz respeito a idealizações e ao amor próprio, maior a ferida narcísica gerada pelo fim da conjugalidade e, consequentemente, maior o sofrimento e demanda de elaboração desse luto.

Exercer a parentalidade de forma conjunta, após o divórcio, implica em manter um relacionamento com o ex-cônjuge, mesmo após o fim do casal conjugal. A Lei da Guarda Compartilhada (Brasil, 2014), a literatura da área (Grzybowski \& Wagner, 2010; Marinho, 2011; Schneebeli \& Menandro, 2014; Ziviani et al, 2012) e também os resultados dessa pesquisa valorizam a convivência dos filhos com ambos os genitores, indicando que a coparentalidade é central no processo de reorganização da família.

Os dados desta pesquisa apontam para situações delicadas que os filhos podem experimentar em relação ao conflito parental, segundo a percepção dos pais. Impossibilidade de diálogo, evitação de conversas sobre um genitor com o outro, conflitos de lealdade, preocupação com conflitos entre os genitores, responsabilidade por articular momentos de encontros familiares, entre outros, foram apontados como recorrentes em crianças e jovens que se encontram nessa situação. Essas vivências demandam certo grau de maturidade e, não raro, os pais também apontaram terem percebido seus filhos mais maduros após o divórcio.

Nesse sentido, percebe-se que os filhos podem ter ganhos e perdas. Quando exercem função de responsabilidade sobre os próprios pais, além de cuidarem de si mesmos, podem não ter como suprir tal demanda e, por isso, estarem em sofrimento. Porém, a situação de crise pode também ser vivida como oportunidade de crescimento, ganho de maturidade e resiliência. Mesmo em um cenário de maior diálogo entre os pais, os filhos são afetados por mudanças em sua vida. Os resultados da pesquisa evidenciaram que a convivência e a rotina sofrem muitas alterações e há grande necessidade de adaptação por parte de todos.

Em suma, o divórcio altera o exercício da parentalidade e traz repercussões para os filhos. Acredita-se que essa situação demanda trabalho psíquico a fim de elaborar o fim da conjugalidade e de que novos investimentos sejam feitos. A 
organização da família e o cuidado conjunto da prole são parte desses investimentos que permanecem, porém precisam ser reinventados após a separação. Os filhos são sujeitos ativos nessa situação, apoiam o funcionamento da família em época de crise, mas não podem ocupar a posição dos genitores. A discriminação entre conjugalidade e parentalidade é essencial no pós-divórcio para que o casal parental atue de uma forma nova e possível para cada um, viabilizando uma coparentalidade que promova saúde emocional na família. 


\section{Referências bibliográficas}

ARAÚJO, M. F. Gênero e família na construção de relações democráticas. In: FÉRES-CARNEIRO, Terezinha. (Org.). Casal e família: permanências e rupturas. São Paulo: Casa do Psicólogo, 2009. p. 9-23.

BARDIN, L. Análise de conteúdo. Lisboa: Edições 70, 2011.

BAUMAN, Z. Amores líquidos: sobre a fragilidade das relações humanas. Rio de Janeiro: Jorge Zahar, 2004.

BIRMAN, J. Laços e desenlaces na contemporaneidade. Jornal de Psicanálise, São Paulo: v. 40, n. 72, p. 47-62, jun. 2007.

BRASIL (País). Lei n. ${ }^{\circ} 11.698$, de 13 de junho de 2008. Altera os arts. 1.583 e 1.584 da Lei n. ${ }^{\circ} 10.406$, de 10 de janeiro de 2002 - Código Civil, para instituir e disciplinar a guarda compartilhada. Disponível em:

<http://www.planalto.gov.br/ccivil_03/_Ato2007-2010/2008/Lei/L11698.htm> Acesso em: 20/08/2015.

Lei n. ${ }^{\circ} 13.058$, de 22 de dezembro de 2014. Altera os arts. 1.583, 1.584, 1.585 e 1.634 da Lei n. ${ }^{\circ}$ 10.406, de 10 de janeiro de 2002 (Código Civil), para estabelecer o significado da expressão "guarda compartilhada" e dispor sobre sua aplicação. Disponível em: < http://www.planalto.gov.br/ccivil_03/_ato20112014/2014/Lei/L13058.htm> Acesso em: 20/08/2015.

BRITO, L. M. T. Família pós-divórcio: a visão dos filhos. Psicologia Ciência e Profissão, v. 27, n. 1, p. 32-45, 2007.

CARTER, B.; McGOLDRICK, M. As mudanças no ciclo de vida familiar: uma estrutura para a terapia familiar. In: CARTER, B.; MCGOLDRICK, M. et al. As mudanças no ciclo de vida familiar: uma estrutura para a terapia familiar. Trad. Maria Adriana Veríssimo Veronese. 2. ed. Porto Alegre: Artes Médicas, 1995. p. 7-29.

EIGUER, A. Desentendimento de casal e luta pelo reconhecimento. In: GOMES, I. C.; LEVY, L. (Orgs.). Atendimento psicanalítico de casal. São Paulo: Zagodoni, 2013. p. 45-59.

FÉRES-CARNEIRO, T. Separação: o doloroso processo de dissolução da conjugalidade. Estudos de psicologia. Natal: UFRN, v. 8, n. 3, p. 367-374, 2013.

FÉRES-CARNEIRO, T.; ZIVIANI, C.; MAGALHÃES, A. S.; PONCIANO, E. L. T. Ser pai (mãe), ser filho(a): a resolução de conflitos em famílias contemporâneas casadas. In: FÉRES-CARNEIRO, T. (Org.). Casal e família: transmissão, conflito e violência, São Paulo: Casa do Psicólogo, 2013. p. 73-98.

FÉRES-CARNEIRO, T; MAGALHÃES, A. S.; HENRIQUES, C. R.; MACHADO, R. N.; ZIVIANI, C. Parentalidade contemporânea sob a ótica dos filhos. In: FÉRES-CARNEIRO, T. (Org.). Família e casal: parentalidade e filiação em diferentes contextos. Rio de Janeiro: PUC-Rio/Proscpetiva, 2015. p. 73-92. 
FREUD, S. Introdução ao narcisismo [1914]. In: FREUD, S. (1914-1916). Obras completas. Introdução ao narcisismo, ensaios de metapsicologia e outros textos (1914-1916). v. 12. Trad. Paulo César de Souza. São Paulo: Companhia das Letras, 2010. p. 13-50.

Luto e melancolia [1915]. In: FREUD, S. (1914-1916). Obras completas. Introdução ao narcisismo, ensaios de metapsicologia e outros textos (1914-1916), v. 12. Trad. Paulo César de Souza. São Paulo: Companhia das Letras, 2010a. p. 171-194.

Repressão [1915]. In: FREUD, S. (1914-1916). Obras completas. Introdução ao narcisismo, ensaios de metapsicologia e outros textos (1914-1916), v. 12. Trad. Paulo César de Souza. São Paulo: Companhia das Letras, 2010b. p. 82-98.

GRZYBOWSKI, L., WAGNER, A.. Casa do pai, casa da mãe: a coparentalidade após o divórcio. Psicologia: teoria e pesquisa, v. 26, p. 77-87, 2010.

HINTZ, H. C., BAGINSKI, P. H. Vínculo conjugal e transição para a parentalidade: fragilidades e possíveis superações. Revista Brasileira de Terapia de Família, v. 4, n. 1, p. 10-22, 2012.

JURAS, M. M.; COSTA, L. F. Divórcio destrutivo e justiça. Revista de Direito Privado, v. 12, p. 265-297, 2011.

KEHL, M. R. Em defesa da família tentacular. In: GROENINGA, G.C.;

PEREIRA, R. C. Direito de família e psicanálise. Rio de Janeiro, Imago, 2003. P. 163-173.

LEBOVICI, S. Diálogo Leticia Solis-Ponton e Serge Lebovici. In: SILVA, M. C. P.; SOLIS-PONTON, L. (Orgs.). Ser pai, ser mãe. Parentalidade: um desafio para o terceiro milênio. São Paulo: Casa do Psicólogo, 2006. p. 21-27.

MANOCHERIAN, J.; PECK, J. S. O divórcio nas mudanças do ciclo de vida familiar. In: CARTER, B.; MCGOLDRICK, M. As mudanças no ciclo de vida familiar: uma estrutura para a terapia familiar. Porto Alegre: Artmed, 1995. p. 291-320.

MARINHO, S. Paternidades de hoje: significados, práticas e negociações da parentalidade na conjugalidade e na residência alternada. Tese de Doutoramento em Ciências Sociais, Instituto de Ciências Sociais da Universidade de Lisboa, Lisboa, Portugal, 2011.

MOGUILLANSKY, R.; NUSSBAUM, S. O amor moderno e o amor passional na clínica vincular. Uma contribuição à questão do amor e o ódio na vida amorosa. In: MOGUILlANSKY, R.; NUSSBAUM, S. Psicanálise vincular, v. 2. São Paulo: Zagodoni, 2011. p. 216-223.

RAPOSO, H. S.; FIGUEIREDO, B. F. C.; LAMELA D. J.; Nunes-Costa, R. A.; CASTRO, M. C.; PREGO, P. Ajustamento da criança à separação ou divórcio dos pais. Psiquiatria Clínica, n. 38, p. 29-33, 2011.

ROUDINESCO, E. A família em desordem. Rio de Janeiro: Jorge Zahar, 2003.

SCHNEEBELI, F. C. F.; MENANDRO, M. C. S. Com quem as crianças ficarão? Representações sociais da guarda dos filhos após a separação conjugal. Psicologia \& Sociedade, v. 26, n. 1, p. 175-184, 2014. 
SINGLY, F. Sociologia da família contemporânea. Rio de Janeiro: Editora FGV, 2007.

SMADJA, E. Le couple et son histoire. Paris: Presses Universitaires de France, 2011.

ZIVIANI, C.; FÉRES-CARNEIRO, T.; MAGALHÃES, A. S. Pai e mãe na conjugalidade: aspectos conceituais e validação de construto. Paidéia, v. 22, n. 52, p. 165-176, 2012. 
Anexos

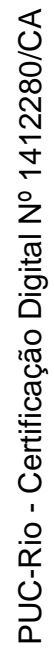




\section{Anexo I}

\section{Ficha biográfica}

\section{Tipo de configuração familiar:}

Idade: anos

Sexo: $M \square \quad F \square$

Profissão:

Religião:

Escolaridade:

Ensino Médio ( $2^{\circ}$ grau) completo

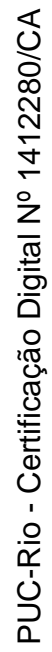

Ensino Superior (Universidade) incompleto $\square$ completo $\square$ Curso:

Especialização $\square$ Mestrado $\square$ Doutorado

Orientação sexual:

Heterossexual $\square \quad$ Homossexual $\square \quad$ Bissexual $\square$

Constituição Familiar:

Cônjuge - Idade: anos Profissão:

Filhos:

$\mathrm{F} \square \mathrm{M} \square$ idade Morando

com:

$\mathrm{F} \square \mathrm{M} \square$ idade Morando

com:

$\mathrm{F} \square \mathrm{M} \square$ idade Morando

com:

$\mathrm{F} \square \mathrm{M} \square$ idade Morando

com:

Filhos sócio-afetivos:

$\mathrm{F} \square \mathrm{M} \square$ idade Morando

com:

$\mathrm{F} \square \mathrm{M} \square$ idade Morando

com:

$\mathrm{F} \square \mathrm{M} \square$ idade Morando

com:

$\mathrm{F} \square \mathrm{M} \square$ idade Morando com: 


\section{Anexo II \\ Roteiro semiestruturado para entrevista}

Pergunta disparadora: Como é ser pai/mãe para você?

- Como os pais acham que foi para os filhos o divórcio e o pós-divórcio.

- Organização da rotina com ambos os genitores.

- Funções de cada genitor.

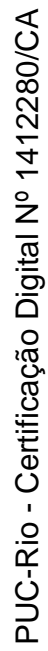

- Existem novos cônjuges e novos irmãos.

- Autonomia e responsabilidades dos filhos. 


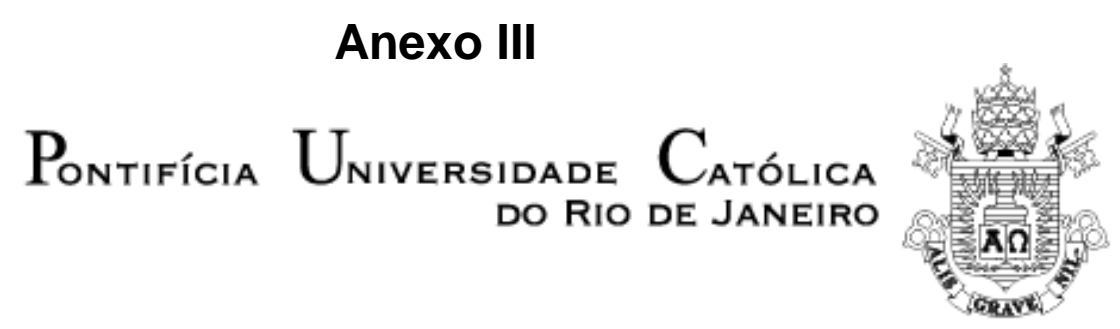

Termo de Consentimento Livre e Esclarecido

Instituição de origem: Pontifícia Universidade Católica do Rio de Janeiro

Título da pesquisa: A parentalidade no pós-divórcio (dissertação de mestrado)

Pesquisadora: Michelle Christof Gorin (migorin@gmail.com / Tel: 99981-1655)

Orientadora: Professora Terezinha Féres-Carneiro (teferca@puc-rio.br / Tel:

99111-0180)

Com este trabalho de pesquisa pretendemos compreender melhor as questões relacionadas ao exercício das funções parentais no pós-divórcio. Assim, o objetivo geral desta investigação é estudar a percepção de pais em relação ao exercício da parentalidade após a separação conjugal.

A pesquisa é realizada a partir de uma entrevista gravada e, posteriormente, transcrita, permanecendo sob a responsabilidade da pesquisadora todo e qualquer dado de identificação. Todas as informações têm caráter confidencial, portanto sua identidade será mantida em sigilo.

Sua participação é voluntária, estando livre para interromper a entrevista quando assim desejar; fazer as perguntas que julgar necessárias; recusar-se a responder perguntas ou falar de assuntos que lhe possam causar qualquer tipo de constrangimento. A participação não causa nenhum dano ao participante. Com sua adesão, você estará contribuindo para conhecermos mais sobre o exercício da parentalidade hoje.

Assinando este Termo de Consentimento, você estará autorizando a pesquisadora a utilizar, em ensino, pesquisa e publicação, as informações prestadas na entrevista, sendo preservada sua identidade e a dos membros da sua família.

$\mathrm{Eu}$, , fui informado(a) sobre o estudo acima referido e compreendi seus objetivos. Tive a oportunidade de fazer perguntas e todas as minhas dúvidas foram respondidas a contento. Este Termo está sendo assinado voluntariamente por mim, em duas vias, uma para mim e outra para a pesquisadora, o que indica meu consentimento para participar dessa pesquisa.

Assinatura do entrevistado

Assinatura da pesquisadora

Rio de Janeiro, 